\title{
EL PERSONAJE DE SANCHO PANZA Y LOS LECTORES DEL SIGLO XVII ${ }^{1}$
}

JAVIER SALAZAR RINCÓN

UNED La Seu d'Urgell (Lleida)

Sancho Panza acompaña a don Quijote a partir del capítulo VII de la primera parte, con el que se inicia la segunda salida del hidalgo, y desde aquel momento Cervantes construye una interesante relación de contrapunto y de influjo mutuo entre los dos personajes, dotando con ello a la novela de una hondura, una calidad e interés humanos y un valor literario permanentes, que en gran parte derivan de la presencia de Sancho y del hábil juego de contrastes e influencias entre el caballero y su escudero. De esta forma, gracias a la antítesis y a la síntesis final que la novela establece entre sus dos caracteres, don Quijote y Sancho Panza han venido a simbolizar las dos facetas primordiales de todo espíritu humano, que al mismo tiempo se oponen y complementan: el ideal y la realidad, el espíritu y la materia, lo soñado y lo tangible, lo poético y prosaico de la vida; y en ello estriba en gran parte, creemos, el hecho de que el Quijote haya ofrecido, y ofrezca todavía hoy, una lección válida para los lectores de cualquier país y época ${ }^{2}$.

\footnotetext{
${ }^{1}$ Ofrezco en las páginas que siguen una versión ligeramente ampliada de la conferencia que, con motivo del aniversario de la muerte de Cervantes y la celebración del Día Mundial del Libro, e invitado por la Embajada de España en Suecia, pronuncié en las universidades de Estocolmo y Uppsala los días 22 y 23 de abril de 1999. Una primera versión de este trabajo fue expuesta ante un joven e interesado auditorio compuesto por alumnos de $3^{\circ}$ de BUP y COU en el Instituto de Bachillerato "Antoni Torroja» de Cervera (Lleida), al que fui invitado en abril de 1994.

${ }^{2}$ Todas las citas del Quijote que aparecen a lo largo del trabajo han sido tomadas de Miguel De Cervantes, Don Quijote de la Mancha, edición del Instituto Cervantes dirigida por Francisco Rico, Barcelona, Instituto Cervantes y Edito-
} 
En la presencia de Sancho hay que buscar el origen de otro de los grandes hallazgos de Cervantes: la interacción e influencia mutua entre los protagonistas, que evolucionan de forma paralela mediante el contagio mutuo, llegando a asimilar cada uno las enseñanzas y hasta la manera de pensar y hablar del otro, de tal manera que Sancho se quijotiza, especialmente en la novela de 1615 , hasta llegar a creer a pies juntillas el encantamiento de Dulcinea o la aventura del caballo Clavileño; y don Quijote va poco a poco pactando con la realidad, viendo ventas y rebaños en lugar de molinos o de ejércitos, y admitiendo, aconsejado por el ventero y por Sancho, que el gasto que hace el huésped en la venta ha de pagarse con dineros contantes y sonantes.

Lo que acabamos de comentar es muy sabido y trillado, algo así como el abecé del cervantista: tópicos que la crítica literaria de todas las épocas ha repetido hasta la saciedad, y que los profesores suelen explicar a sus alumnos un año tras otro. Y sin embargo, tales ideas, aunque se hallaran implícitas en el libro, son el resultado de la lectura e interpretación del Quijote llevada a cabo por la crítica moderna, a partir del siglo XIX especialmente: Fueron los escritores y eruditos de la época romántica, alemanes sobre todo, quienes vieron por primera vez encarnada en el hidalgo manchego la quintaesencia del idealismo, y en don Quijote y en Sancho, los símbolos respectivos del ideal y la realidad, de la poesía y la prosa de nuestra existencia ${ }^{3}$, una idea que hizo suya, sin discrepancias notables, gran parte de la crítica literaria posterior, incluso en el siglo $\mathrm{XX}^{4}$; y en cuanto a la quijotización que sufre Sancho Panza y la sanchificación de don Quijote, aunque se ha-

rial Crítica, 1998. En cada caso indicamos entre paréntesis la parte con números romanos, y a continuación el capítulo y la(s) página(s).

3 Véase LEOPOLDo Rius, Bibliografía crítica de las obras de Miguel de Cervantes Saavedra, Madrid, Librería M. Murillo, 1895-1905, 3 vols., especialmente la sección titulada "Cervantes juzgado por los extranjeros», vol. III, pp. 189 y ss.; J. J. A. BerTRAND, Cervantès et le Romantisme allemand, Paris, Félix Alcan, 1914; del mismo autor, Cervantes en el país de Fausto, Madrid, Ediciones Cultura Hispánica, 1950; WERnER BRÜGgemann, Cervantes und die Figur des Don Quijote in Kunstanschauung und Dichtung der Deutschen Romantik, Münster / Westfalen, Aschendorff, 1958; CÉSAR REAL DE LA RIVa, "Historia de la crítica e interpretación de la obra de Cervantes», Revista de Filología Española, XXXII, 1948, pp. 107150, especialmente, pp. 131 y ss.; FRANCo MEREgALLI, "Cervantes nella critica romantica tedesca. Stato degli Studi", Annali della Facoltà di Lingue e Letterature Straniere di Ca' Foscari, XI, 1972, pp. 381-395; y DANIEL EISENBERG, "La influencia de Don Quijote en el Romanticismo", en La interpretación cervantina del Quijote, Madrid, Compañía Literaria, 1995, pp. 193-208.

${ }^{4}$ Véase ANThony J. Close, The Romantic Approach to "Don Quixote»: A Critical History of the Romantic Tradition in "Quixote» Criticism, Cambridge, Cambridge University Press, 1978. 
yan convertido en un lugar común de la crítica cervantina ${ }^{5}$, fue Salvador de Madariaga quien desarrolló por primera vez la idea con cierto detalle, en un conocido ensayo publicado en $1926^{6}$.

Dicho esto, podemos ya plantearnos la cuestión que encierra el título de nuestro trabajo, y que desarrollaremos en las páginas que siguen: ¿Qué representaba Sancho Panza para los lectores del siglo XVII que, sin gran bagaje erudito - al parecer fueron muchos $^{7}$-, se acercaban a la obra buscando entretenimiento?, ¿qué aspectos llamaron su atención?, ¿qué lectura hicieron del personaje?

\section{Sancho Panza y Gandalín, escuderos}

Un primer detalle en que deberíamos fijarnos, y que sin duda advirtieron los lectores coetáneos, es el de las raíces literarias del personaje de Sancho, que, como las de su amo, han de buscarse en las novelas de caballerías, un aspecto que Eduardo Urbina ha examinado detenidamente ${ }^{8}$ : En efecto, si don Quijote es una parodia viva de los héroes caballerescos, su fiel acompañante tiene bastante que ver, como es lógico, con los escuderos que protagonizan tales libros, en primer lugar cuando sus rasgos más serios

${ }^{5}$ Entre otros trabajos, pueden verse, a modo de ejemplo, los de Victor R. B. OELSCHLÄGER , "Sancho's Zest for the Quest», Hispania, XXXV, 1952, pp. 18-24; y William B. García, "La educación de Sancho Panza», Revista de Estudios Hispánicos, III, 1969, pp. 257-263.

"SAlvador DE MADARIAGa, Guía del lector del "Quijote». Ensayo psicológico sobre el "Quijote», Madrid, Espasa-Calpe, Col. Austral, $2^{\text {a }}$ edic., 1978, pp. 137-160.

${ }^{7}$ La historia es tan clara, explica Sansón Carrasco al iniciarse el Quijote de 1615, "que no hay cosa que dificultar en ella: los niños la manosean, los mozos la leen, los hombres la entienden y los viejos la celebran; y, finalmente, es tan trillada y tan leída y tan sabida de todo género de gentes, que apenas han visto algún rocín flaco, cuando dicen: "Allí va Rocinante». Y los que más se han dado a su letura son los pajes: no hay antecámara de señor donde no se halle un Don Quijote, unos le toman si otros le dejan, estos le embisten y aquellos le piden" (II, 3, 652-53). Véanse, a propósito de todo ello, los trabajos de MAXIME CHEVALIER ("Don Quichotte et son public", en Livre et lecture en Espagne et en France sous l'Ancien Régime. Colloque de la Casa de Velázquez, Paris, A.D.P.F., 1981, pp. 119$125)$, quien ha señalado cómo el gusto del público por las burlas y los elementos novelescos explicaría el éxito comparativamente mucho mayor del Quijote de 1605 y de la Novelas ejemplares respecto al de 1615; y JosÉ MONTERo REGUERA ("Aspectos de la recepción del Quijote en el siglo XVII. Cervantes relee su obra", Edad de Oro, XII, 1993, pp. 203-218), quien señala los datos, presentes en la propia obra cervantina, que nos permiten calibrar el éxito y conocer al público lector de la primera parte.

${ }^{8}$ EdUARdo URBINA, El sin par Sancho Panza: parodia y creación, Barcelona, Anthropos, 1991. 
y heroicos aparecen parodiados e invertidos en la figura de Sancho, y también porque en su faceta más desenfadada y humorística, nuestro personaje guarda estrecha relación con los enanos de las novelas artúricas y con ciertos escuderos presentes en tales libros, y de manera especial con el Gandalín de Amadís de Gaula, una fuente a la que en ocasiones alude el propio autor ${ }^{9}$ y que sin duda estuvo en la mente de sus primeros lectores, como lo demuestra la tragicomedia de Guillén de Castro Don Quijote de la Mancha, una imitación temprana de la obra cervantina en cuya última jornada asistimos al diálogo siguiente:

\author{
Don QuiJote \\ ¿Qué farás buen Panza, al fin, \\ cuando por mía confirme \\ la primer ínsula firme? \\ Serás otro Gandalín. \\ SANCho PANZa \\ ¿Quién fue Gandalín, señor? \\ DON QUIJOTE \\ Fízole, ¡son maravillas! \\ de cincuenta y tantas villas \\ su amo Gobernador. \\ Seráslo tú, aunque me cueste \\ la vida. \\ SANCHO PANZA \\ Dame vasallos, \\ que yo sabré gobernallos; \\ ¡a fe que se las atieste! ${ }^{10}$
}

\begin{abstract}
${ }_{9}$ Tras el episodio de los Batanes, don Quijote reprende a su escudero recordándole que «en cuantos libros de caballerías he leído, que son infinitos, jamás he hallado que ningún escudero hablase tanto con su señor como tú con el tuyo. $\mathrm{Y}$ en verdad que lo tengo a gran falta, tuya y mía: tuya, en que me estimas en poco; mía, en que no me dejo estimar en más. Sí, que Gandalín, escudero de Amadís de Gaula, conde fue de la ínsula Firme, y se lee dél que siempre hablaba a su señor con la gorra en la mano, inclinada la cabeza y doblado el cuerpo more turquesco" (I, 20, 221). Y de regreso a la aldea: "Yo no sé que haya más que decir: sólo me guío por el ejemplo que me da el grande Amadís de Gaula, que hizo a su escudero conde de la Ínsula Firme, y, así, puedo yo sin escrúpulo de conciencia hacer conde a Sancho Panza, que es uno de los mejores escuderos que caballero andante ha tenido" (I, 50, 573).

${ }^{10}$ Guillén DE CASTRo, Don Quijote de la Mancha, jornada III, escena 5, edic. de Luciano García Lorenzo, Salamanca, Anaya, 1971, pp. 149-150. La obra fue escrita entre 1605 y 1606, según COURTNEY BRUERTON, "The Chronology of the 'comedias' of Guillén de Castro", Hispanic Review, XII, 1944, pp. 89-151, p. 116.
\end{abstract}




\section{UN LABRADOR POBRE Y CON HIJOS}

Pero en el momento de la publicación del Quijote, el personaje de Sancho tuvo sin duda otros significados, que intentaremos señalar en la páginas que siguen; y el primer dato que tendremos en cuenta para lograrlo se halla en el capítulo cuarto de la primera parte de la obra, en que Cervantes, al nombrar a Sancho Panza por primera vez, nos dice que don Quijote:

...determinó volver a su casa y acomodarse de todo, y de un escudero, haciendo cuenta de recebir a un labrador vecino suyo que era pobre y con hijos, pero muy a propósito para el oficio escuderil de la caballería (I, 4, 62).

Y al iniciarse la segunda salida:

En este tiempo solicitó don Quijote a un labrador vecino suyo, hombre de bien - si es que este título se puede dar al que es pobre-, pero de muy poca sal en la mollera (I, 7, 91).

Como advierte el narrador, y así debieron de percibirlo los lectores de la época, Sancho es ante todo un labrador pobre y de poca sal en la mollera, dos detalles que hoy nos pueden parecer intranscendentes, pero que, contrastados con otros testimonios coetáneos, resultan reveladores para profundizar en la significación que la novela pudo tener en el momento de su publicación. Y empezaremos recordando que la palabra labrador, más aun si iba acompañada por el calificativo de pobre, como ocurre a Sancho Panza, poseyó en aquella época un significado muy preciso, diametralmente opuesto al que pueda tener el mismo término en nuestra Europa de la globalización, los seguros agrarios y las subvenciones del gobierno de Bruselas.

En efecto, si exceptuamos los grandes núcleos urbanos, en que la artesanía y el comercio a gran escala han contribuido a crear un modelo de sociedad aburguesada y precapitalista, la Europa de hace cuatrocientos años era todavía un amplio espacio semifeudal ${ }^{11}$ en que la minoría aristocrática y la Iglesia monopolizan el poder y la riqueza, mientras que la gran mayoría de la población, el estado llano, trabaja en el campo y vive en unas condiciones que apenas alcanzan el nivel de la simple subsistencia. Y si nos trasladamos a la España de la época, y más concretamente a la región de la Mancha, en que Cervantes ambienta la novela, com-

${ }^{11}$ FERNAND BRAUDEL, El Mediterráneo y el mundo mediterráneo en la época de Felipe II, México, FCE, $2^{\text {a }}$ edic., 1976, 2 vols., vol. II, p. 71. 
probamos que la clase social de los labradores, a la cual pertenece Sancho Panza, representa aproximadamente el ochenta por ciento de la población total ${ }^{12}$, y que sus condiciones de vida son lamentables, si damos crédito a testimonios como el de Cristóbal Suárez de Figueroa, quien, en 1617, pone este comentario en boca de uno de los personajes de su obra El Pasajero:

De las cosas que me causan admiración más crecida es una el excesivo trabajo de los agricultores. Puedo decir que nunca gozan día bueno. ¿Qué fríos, lluvias y nieves no padecen de invierno? ¿Qué ardores y cansancios no sufren por estío? A muchos, particularmente segadores, ahoga el demasiado calor en las mismas hazas. Visten lo más humilde, lo de más bajo precio. Comen lo peor y más desechado, siempre con penuria y calamidad. Toda su fatiga y sudor se van en pagar las rentas, y iojalá que alcanzase! Cuando la cosecha del pan es razonable, es malísima la del vino. El año pasado vi, haciendo un viaje, ofrecer cincuenta arrobas de vino por un carro de paja. Habíase cogido en la Mancha casi ningún trigo, y menos cebada, y recelosos de que el ganado mayor se les muriese, salían a buscar sustento para él muchas leguas de sus casas ${ }^{13}$.

Dos años más tarde, en 1619, al glosar una consulta dirigida por el Consejo de Castilla al rey Felipe III, Pedro Fernández de Navarrete apuntaba algunas causas concretas de la miseria que padecen los labriegos:

Cuando considero lo que dijo Cicerón, que entre todas las cosas de que los hombres sacan ganancia, ninguna hay mejor, más abundante, más dulce ni más digna de los hombres ingenuos y nobles que la agricultura [...]. Y cuando después pongo los ojos en la miseria, en el abatimiento, en el desprecio y pobreza a que ha llegado en Castilla este tan importante estado, atribuyo parte de tan grave daño a que la mayor [parte] de los gravámenes y cargas está impuesta sobre los flacos hombros deste afligido gremio, contra quien se cortan siempre las cavilosas plumas de los escribanos, se afilan las espadas de los soldados, y se encaminan las perjudiciales quimeras de los arbitristas ${ }^{14}$.

Y otro tratadista, Fray Benito de Peñalosa, escribe en 1629:

El estado de los Labradores de España en estos tiempos está el más pobre y acabado, miserable y abatido de todos los demás estados, que parece que todos ellos juntos se han aunado y conjurado a destruyrlo y

12 Manuel Fernández Álvarez, La sociedad española en la época del Renacimiento, Salamanca, Anaya, 1970, p. 106.

13 CRistóbal SuÁrez de Figueroa, El Pasajero. Advertencias utilísimas a la vida humana, edic. de Francisco Rodríguez Marín, Madrid, Renacimiento, 1913, p. 345.

14 PEDRo FERNÁNDEZ De NAVARReTe, Conservación de monarquías y discursos políticos sobre la gran consulta que el Consejo hizo al señor rey don Felipe III, Madrid, Atlas, 1947 (BAE, 25), p. 532. 
arruynarlo: y a tanto ha llegado, que suena tan mal el nombre de Labrador, que es lo mismo que pechero, villano, grossero, malicioso, y de ahí baxo...15

Pero no todos los labradores vivían en la miseria, ni los testimonios que acabamos de citar son aplicables al conjunto del campesinado: Si acudimos a las Relaciones de los pueblos de España, interesante encuesta iniciada en el Reino de Castilla por orden del rey Felipe II, en que se nos proporcionan curiosas noticias acerca de la actividad económica y la vida social de aquella época ${ }^{16}$, los informadores suelen distinguir con nitidez dos categorías básicas dentro del conjunto aparentemente homogéneo de la población campesina perteneciente al estado llano: De un lado los labradores propiamente dichos, que poseen tierras, algunas yuntas de mulas e incluso gentes a su servicio, y gozan en ocasiones de una posición acomodada; y, de otro, los jornaleros o trabajadores, que, aunque sean propietarios de algún pegujal o huerta, no tienen más hacienda que la fuerza de sus brazos y viven por lo general en condiciones precarias. Los vecinos de Villalvilla (Madrid), por ejemplo, responden así a la pregunta núm. 42 de las Relaciones:

...la tercia parte de los vecinos son labradores que ganan por pan y vino $\mathrm{y}$ aceite y ganados menudos y mayores, y las otras dos partes son vecinos trabajadores que ganan de comer por el trabajo de sus manos al azadón $^{17}$.

En Gerindote (Toledo) hay cien vecinos, de los cuales uno solamente es hidalgo, mientras que el resto de la población está formada por «labradores de un par de mulas, que serán entre quince o veinte, $\mathrm{y}$ los demás son trabajadores» ${ }^{18}$. Y en Santo Domingo del Valle, otra localidad de Toledo, entre los ciento veinte vecinos del pueblo, aparte de tres hidalgos:

...habrá como cincuenta labradores y los más de ellos no tienen más de un par de bueyes con que labran y alguna viña y una casa en que viven, y que no les conocen otras heredades ni tierras, y toda la más gente son trabajadores y viven del trabajo de sus $\operatorname{manos}^{19}$.

${ }^{15}$ FRaY Bentto de PeÑalosa y Mondragón, Libro de las cinco excelencias del español que despueblan a España para su mayor potencia y dilatación. Pamplona, 1629, fol. 169.

${ }_{16}$ Relaciones histórico-geográfico-estadísticas de los pueblos de España hechas por iniciativa de Felipe II, edic. de Carmelo Viñas Mey y Ramón Paz, Madrid, CSIC 1949-1971, cinco volúmenes que incluyen los datos correspondientes a la Provincia de Madrid (1949), Reino de Toledo. Primera parte (1951), Reino de Toledo. Segunda parte (1963), Reino de Toledo. Tercera parte (1963), y Ciudad Real (1971).

17 Relaciones. Provincia de Madrid, p. 693.

${ }_{18}$ Relaciones. Reino de Toledo. Primera parte, p. 426.

${ }^{19}$ Relaciones. Reino de Toledo. Segunda parte, p. 431. 
Los labradores en sentido estricto, es decir, los propietarios de tierras, representaban en aquel momento un tercio aproximadamente de la población rural de Castilla la Nueva, y entre ellos existió una minoría de labradores ricos - alrededor del cinco por ciento del conjunto de la población rural- que llegó a constituir una auténtica oligarquía dentro del campo castellano, con una riqueza y un conjunto de privilegios de hecho iguales o superiores a los de muchos hidalgos y otros nobles de baja categoría ${ }^{20}$ : Es el sector social al que pertenecen personajes del Quijote ${ }^{21}$ como Juan Haldudo el rico, el vecino de Quintanar que maltrata a Andrés; Marcela, la pastora de la que se enamora perdidamente Grisóstomo; Dorotea, esposa de don Fernando; Camacho, el protagonista de las opíparas bodas; o el muchacho que engaña a la hija de doña Rodríguez, hijo de un labrador riquísimo con quien el Duque no desea tener pleitos, ya que, según explica la dueña, en lugar de obligar al mozo a que cumpla su palabra y se case con la joven, el señor:

...hace orejas de mercader y apenas quiere oírme, y es la causa que como el padre del burlador es tan rico y le presta dineros y le sale por fiador de sus trampas por momentos, no le quiere descontentar ni dar pesadumbre en ningún modo (II, 48, 1021).

Frente a los labradores ricos, los trabajadores son jornaleros del campo que, aunque dispongan a veces de una pequeña porción de tierra para labrar, trabajan la mayor parte del año en las posesiones de un noble o un plebeyo acomodado, representan entre la mitad y los dos tercios de la población de las aldeas, y son el sector más abatido y pobre del campo castellano ${ }^{22}$, hasta tal punto que, como veremos después, la condición social del jornalero viene a ser en muchos documentos de la época sinónimo de po-

${ }^{20}$ NoËL SALOMON, La vida rural castellana en tiempos de Felipe II, Barcelona, Planeta, 1973, pp. 275-291; y DAVID E. VASSBERG, Tierra y sociedad en Castilla. Señores, poderosos y campesinos en la España del siglo XVI, Barcelona, Crítica, 1986, pp. 178-186. En el norte de Castilla, en la comarca de la Bureba en concreto, las proporciones eran similares, según los cálculos de Francis Brumont: Los labradores constituían el 35 por ciento de la población rural, y entre ellos sobresale una minoría de campesinos ricos (FRANCIS BRUMONT, Campo y campesinos de Castilla la Vieja en tiempos de Felipe II, Madrid, Siglo XXI, 1984, pp. 214-220).

${ }^{21}$ Véase NoËL SALOMON, "Sobre el tipo del labrador rico en el Quijote», Beiträge zur Romanischen Philologie, Berlín, 1967, pp. 105-113; y JAVIER SALAZAR RINCóN, El mundo social del "Quijote», Madrid, Gredos 1986, pp. 210-215.

22 NoËL SALOMON, La vida rural, pp. 264-274; DAVID E. VASSBERG, Tierra y sociedad en Castilla, pp. 187-193; y para el norte de Castilla, donde el número de jornaleros no sobrepasaba el veinte por ciento de la población rural, FRANCIS BRUmont, Campo y campesinos de Castilla la Vieja, pp. 220-221. 
breza y hambre, un detalle al que hoy no prestamos excesiva atención cuando nos acercamos al Quijote, pero que debió de resultar evidente para los lectores coetáneos de Cervantes.

$\mathrm{Y}$, en efecto, por su condición de labrador pobre y sin posesiones, Sancho pertenece al grupo social de los trabajadores o jornaleros del campo, gentes que a duras penas subsisten con el jornal que perciben labrando en tierras ajenas ${ }^{23}$. Ya en su infancia, Sancho Panza sirvió como cabrerizo (II, 41, 965) y porquero (II, $42,970)$, y «después, algo hombrecillo, gansos fueron los que guardé, que no puercos» (ibíd.). Al hacerse cargo del gobierno de la ínsula, "sacado de gobernar un hato de cabras, no pueden imaginar para qué gobierno pueda ser bueno» (II, 52, 1057); y al finalizar el efímero mandato, el propio Sancho explica que los trabajos a los que está acostumbrado son «arar y cavar, podar y ensarmentar las viñas», tras lo cual añade:

Mejor me está a mí una hoz en la mano que un cetro de gobernador, más quiero hartarme de gazpachos que estar sujeto a la miseria de un médico impertinente que me mate de hambre, y más quiero recostarme a la sombra de una encina en el verano y arroparme con un zamarro de dos pelos en el invierno, en mi libertad, que acostarme con la sujeción del gobierno entre sábanas de holanda y vestirme de martas cebollinas (II, 53, 1065).

Al preguntarle don Quijote a cuánto ascendería su salario, Sancho nos vuelve a proporcionar interesantes noticias acerca de sus ocupaciones y su condición social:

Cuando yo servía - respondió Sancho- a Tomé Carrasco, el padre del bachiller Sansón Carrasco, que vuestra merced bien conoce, dos ducados ganaba cada mes, amén de la comida. Con vuestra merced no sé lo que puedo ganar, puesto que sé que tiene más trabajo el escudero del caballero andante que el que sirve a un labrador, que, en resolución, los que servimos a labradores, por mucho que trabajemos de día, por mal que suceda, a la noche cenamos olla y dormimos en cama (II, 28, 864-65).

Y en otra ocasión, narrando una historia chusca en presencia de los duques, el escudero recuerda su condición de jornalero sujeto a la emigración y el trabajo estacional, dos males endémicos del campo español hasta nuestros días, y común durante el periodo que estudiamos ${ }^{24}$ : «dicen que hizo una muerte de un án-

23 JAVIER SALAZAR RINCÓN, El mundo social del "Quijote», pp. 160 y ss.

${ }^{24}$ Las Relaciones ofrecen al respecto testimonios como el de Alcabón (Toledo), donde «Toda la gente deste pueblo es muy pobre [...] y las granjerías de todos ellos son arar el que tiene bueyes y el que no los tiene trabajar, o cavar o segar y varear la aceituna a su tiempo con los señores que tienen aquí sus heredades, 
gel, que yo no me hallé presente, que había ido por aquel tiempo a segar a Tembleque» (II, 31, 886).

Alonso Fernández de Avellaneda, que a menudo insiste en los orígenes sociales del personaje, aprovechó y amplió todos estos pormenores en la continuación apócrifa de la obra, lo cual viene a ser una prueba fehaciente de la atención que numerosos lectores del Quijote, el propio Avellaneda entre ellos, debieron de prestar a estos detalles ${ }^{25}$. Así, cuando, en el capítulo tercero, Sancho viste la armadura de su amo, el comentario que le viene a la cabeza es el siguiente: «Pardiez que aquestas planchas parecen un capote, y si no fueran tan pesadas, eran lindísmas para segar, y más con estos guantes ${ }^{26}$. Estando en una venta cerca de Alcalá, el falso Sancho explica que, antes de volverse moro y ascender a alfaquí y a gran Bajá:

...querría más llegar primero a mi lugar a dar cuenta de mí a dos bueyes que tengo en casa, seis ovejas, dos cabras, ocho gallinas y un porquete, y a despedirme de Mari Gutiérrez en lengua moruna ${ }^{27}$.

Al encontrarse en la corte, embutido en unas calzas apretadas, nuestro personaje exclama:

¡Oh hideputa, y qué bellaca cosa son para segar! No me atrevería ya a segar con ellos doce hazas el día por todo el mundo ${ }^{28}$.

Y cuando, también en Madrid, se le ofrece la posibilidad de entrar como asalariado en casa del Archipámpano, las labores a las que Sancho imagina que deberá dedicarse no son las de los sirvientes de los palacios y cortes, sino las propias de un jornalero del campo:

y otras veces van a trabajar a Torrijos y a otras partes a do hallan que trabajar» (Relaciones. Reino de Toledo. Primera parte, p. 31). Véase Nö̈l SAlomon, La vida rural, pp. 271-272; y DAVID E. VASSBERG, The Village and the Outside World in Golden Age Castile. Mobility and Migration in Everyday Rural Life, Cambridge, Cambridge University Press, 1996, pp. 67-85.

${ }^{25}$ En efecto, «estudiar a Avellaneda es estudiar la recepción contemporánea del Quijote, nos guste o no nos guste lo que encontramos en sus páginas», según ha recordado recientemente JAMES IFFLAND (De fiestas y aguafiestas: Risa, locura e ideología en Cervantes y Avellaneda, Madrid y Frankfurt am Mein, Universidad de Navarra, Iberoamericana y Vervuert, 1999, p. 17).

${ }^{26}$ Alonso Fernández de Avellaneda, El ingenioso hidalgo don Quijote de la Mancha, que contiene su tercera salida y es la quinta parte de sus aventuras, parte $5^{\text {a }}$, cap. 3, edic. de Fernando G. Salinero, Madrid, Castalia, 1999, p. 88.

${ }^{27}$ Ibíd., parte $7^{\text {a }}$, cap. 26 , p. 351 .

${ }^{28}$ Ibid., parte $7^{\text {a }}$, cap. 34, p. 432. 
Por eso, si lo determina hacer, no hay sino efetuarlo, y encomendarme su par de mulas, y decirme cada noche lo que tengo de hacer a la mañana, y adónde tengo de ir a arar o a dar tal vuelta a tal o tal restrojo; y de lo demás déjeme el cargo a mí, que no se descontentará de mi labor.

Agora sólo resta saber si las tierras de vuesa merced que tengo de sembrar este otoño están lejos; tras que, como no las sé, será menester ir a ellas el domingo que viene, y también conocer las mulas y saber qué resabios tienen, y si tienen buenas coyundas y todo el demás aparejo; porque no quiero diga después de mí vuesa merced que soy descuidado ${ }^{29}$.

El trabajador del campo se ve condenado a arrastrar una vida llena de penalidades, servidumbres y miseria, por lo que no es extraño que Cervantes utilice en dos ocasiones, como ya vimos, el calificativo de pobre para referirse a Sancho Panza, ya que, en efecto, en el lenguaje de la época los términos jornalero y pobre frecuentemente funcionan como sinónimos ${ }^{30}$. Fernando Álvarez de Toledo, por ejemplo, distinguía en un memorial de 1602 tres estados o grupos sociales básicos en la sociedad de aquella época:

...el uno de ricos, el otro de pobres y el otro de los que tienen moderado caudal con que pasar. En el estado de los pobres se comprenden los que, no teniendo casa, ni viña, juro, ni censo, ni caudal para contratar, ni bienes raíces, ni oficio con que ganar de comer, se sustentan del jornal que ganan con el trabajo de su persona ${ }^{31}$.

También en las Relaciones de Cobeña (Madrid), se nos dice que:

...hasta ochenta labradores vecinos de esta villa labran sus haciendas con mulas y bueyes, labrando la tierra para coger pan, y otra parte son jornaleros y pobre gente que no tienen con que labrar y en que labrar...32

\section{Y en Argamasilla de Alba (Ciudad Real):}

A los cuarenta capítulos se dice que en esta villa habrá doscientos labradores que tengan mulas y otras alimañas conque labrar, y que lo

\footnotetext{
${ }^{29}$ Ibíd., parte $7^{\text {a }}$, cap. 35 , pp. 444-445.

30 José ANTONio MARAVALL, "Pobres y pobreza del medievo a la primera modernidad», Cuadernos Hispanoamericanos, 367-368, enero-febrero 1981, pp. 189-242.

31 Fernando Álvarez de Toledo, Medios propuestos a Su Majestad tocantes al socorro y desempeño del Reino, Madrid, 1602, fol. 13. Cit. por JosÉ LUIS SUREDA CARRIÓN, La Hacienda castellana y los economistas del siglo XVII, Madrid, CSIC, 1949, p. 167.

32 Relaciones. Provincia de Madrid, p. 187.
} 
restante del estado de los pecheros hay oficiales y jornaleros y mozos de soldada y pastores y otra gente pobre.... ${ }^{33}$

Pero las Relaciones aun nos ofrecen testimonios más patéticos, cuando los informantes clasifican a los habitantes de un lugar en dos grandes grupos: los que tienen que comer, es decir, los propietarios de tierras, y los jornaleros y otra gente pobre. Así ocurre en Esquivias (Toledo), el pueblo natal de Catalina Salazar, en que el propio Cervantes vivió largas temporadas, y donde "los cien vecinos del dicho pueblo ternán de comer, y los demás son pobres jornaleros ${ }^{34}$; o en Carabaña (Madrid), en que los encuestados «declararon que hay gente que tienen de comer para pasar su vida, y que también hay gente pobre» ${ }^{35}$.

Tal vez los testimonios citados contengan una gran dosis de exageración, destinada a ahorrar a las gentes del lugar una vuelta más de rosca en el inflexible sistema fiscal con que la monarquía de los Austrias exprimió a los labradores, especialmente en el Reino de Castilla, aunque, si acudimos a otros testimonios de la época, los datos que aportan las Relaciones no parecen desproporcionados, y coinciden con los que indirectamente nos suministra el autor: La familia de Sancho Panza está compuesta de cuatro miembros, y nuestro personaje gana dos ducados al mes sirviendo a Tomé Carrasco, según vimos ya (II, 28, 865); y en otro momento, al lamentar la pérdida de su rucio, Sancho nos dice que el asno era el «sustentador de la mitad de mi persona, porque con veinte y seis maravedís que ganabas cada día mediaba yo mi despensa» (I, 23, 1234). No es fácil establecer una equivalencia exacta entre dichos ingresos y la moneda actual ${ }^{36}$, aunque si recurrimos de nuevo a los datos que proporcionan otras fuentes coetáneas, y el propio Cervantes en diversos pasajes de su obra, podemos formarnos una idea bastante exacta de lo que tales cantidades podían representar, y de las penosas condiciones en que viven el labriego y su familia.

Los veintiséis maravedís que aporta el asno representan la mitad del ingreso diario de los Panza, como acabamos de ver; la otra mitad (veinticinco maravedís) resulta de dividir los dos ducados que Sancho gana cada mes entre sus treinta días, con lo cual obtenemos la suma total de cincuenta y un maravedís, o lo que es lo mismo, un real y medio de presupuesto diario, cantidad ínfima en

\footnotetext{
${ }^{33}$ Relaciones. Ciudad Real, p. 102.

${ }^{34}$ Relaciones. Reino de Toledo. Primera parte, p. 402.

${ }^{35}$ Relaciones. Provincia de Madrid, p. 172

${ }^{36}$ En aquellos años el ducado equivalía en el Reino de Castilla a once reales y a 374 maravedís, y cada real, por consiguiente, a 34 maravedís.
} 
una época en que un carpintero ganaba al día algo más de doscientos maravedís en Castilla la Nueva y cerca de trescientos en Andalucía $^{37}$ - cuatro o cinco veces más que Sancho Panza-, y en que una libra de queso valía cuarenta maravedís, una libra de manteca cincuenta maravedís, y una de sardinas sesenta, es decir, el equivalente a los ingresos diarios de nuestro labriego ${ }^{38}$. Y si acudimos al testimonio del propio Cervantes, la comparación resulta igualmente desventajosa para la economía del jornalero manchego: Los esportilleros de Sevilla, según explica uno de ellos en la novela Rinconete y Cortadillo, ganan por aquellos años hasta cinco o seis reales en un día ${ }^{39}$, cuatro veces más que Sancho; según el arbitrista de El coloquio de los perros, el presupuesto mínimo diario para la alimentación de una persona era en aquel momento de un real y medio ${ }^{40}$, la misma cantidad con que han de sustentarse y hacer frente a otros gastos los cuatro miembros de la familia de nuestro personaje; Teresa Panza se queja de que "en la corte son los gastos grandes: que el pan vale a real, y la carne, la libra a treinta maravedís, que es un juicio» (II, 52, 1058); cuando el hidalgo redacta su testamento, establece, entre otras cosas, que al Ama se le den veinte ducados para comprar un vestido (II, 74, 1220), es decir, una cantidad equivalente al salario que Sancho habría obtenido trabajando diez meses al servicio de Tomé Carrasco; y al propio autor, cuando sirvió como proveedor de la Armada, en 1587, se le asignó un salario de doce reales diarios ${ }^{41}$, una cantidad ocho veces superior a los ingresos que su personaje iba a obtener casi veinte años después.

Si recurrimos de nuevo al testimonio del Quijote apócrifo, con el fin de calibrar la opinión media que los lectores contemporáneos tuvieron del personaje, descubrimos que la situación económica del falso Sancho, a la que también se alude con frecuencia, no es mucho más halagüeña: Ante la posibilidad de entrar a servir de mozo con el Archipámpano, y exagerando sin duda, el labriego advierte: «puedo ganar cada día en mi lugar dos reales y medio y comida, sin andarme a caza de gangas ${ }^{42}$, es decir, unos

37 EARL J. Hamilton, El tesoro americano y la revolución de los precios en España, 1501-1650, Barcelona, Ariel, 1975, p. 418.

${ }^{38}$ Ibíd., pp. 364-365. Los precios corresponden a Castilla la Nueva y al año 1600.

${ }^{39}$ Miguel De Cervantes SaAvedra, Novelas ejemplares, en Obras completas, edic. de Ángel Valbuena Prat, Madrid, Aguilar, $18^{\text {a }}$ edic., 1986, 2 vols., vol. II, p. 83.

40 Ibid., p. 293.

${ }^{41}$ LUIS ASTRANA MARÍn, Vida ejemplar y heroica de Miguel de Cervantes Saavedra, Madrid, Reus, 1948-1958, 7 vols., vol. IV, p. 158.

${ }^{42}$ Alonso FernánDeZ DE Avellaneda, El ingenioso hidalgo don Quijote de la Mancha, edic. cit., parte $7^{\text {a }}$, cap. 35, p. 443. 
cinco ducados y medio mensuales, si descontamos los domingos y festivos; aunque, a la hora de la verdad, se conformaría con bastante menos:

Verdad es que si el señor Arcapámpanos me asegurase un ducado cada mes y dos o tres pares de zapatos por un año, con cédula de que no se lo había de poner después en pleito, y vuesa merced saliese por fianza dello, sin duda ternía mozo en mí para muchos días ${ }^{43}$.

Cuando el ventero se enfurece con la gallega que sirve en la venta, le echa en cara el "haberos comprado esa sayuela, que me costó diez y seis reales, y los zapatos tres y medio» ${ }^{44}$ : en total veinte reales, que Sancho conseguiría trabajando casi dos meses con el Archipámpano; y el falso Quijote gasta en vestir a Bárbara con una saya, jubón y ropa colorada, doce ducados ${ }^{45}$, el equivalente a la soldada de un año de nuestro labriego.

Llegados a este punto, nuestro discreto lector o inteligente lectora empezará a preguntarse por el valor de todas estas minucias con vistas al disfrute y comprensión de la genial novela, y por la relación que tales detalles guardan con el asunto que nos hemos propuesto desarrollar en el presente trabajo, y tal vez recordará ciertas palabras de don Quijote que vienen en tales casos como anillo al dedo, tanto, que parecen escritas con la mira puesta en nuestro gremio, el de los exégetas de la literatura:

...que hay algunos que se cansan en saber y averiguar cosas que después de sabidas y averiguadas no importan un ardite al entendimiento ni a la memoria (II, 22, 814).

Y sin embargo, son estos y otros detalles relativos a la condición social del personaje, esparcidos aquí y allá a lo largo de la obra, los que contribuyen, no sólo a hacer creíble la historia, reforzando su verosimilitud, sino también a conseguir que el lector, especialmente el contemporáneo de Cervantes, comprenda y justifique las motivaciones íntimas de Sancho, y, en concreto, por qué un hombre de bien con mujer e hijos, sensato aparentemente, es capaz de abandonar su hogar, siguiendo a un hidalgo loco, para engolfarse junto a él en las aventuras más disparatadas. $\mathrm{Y}$ en este sentido conviene recordar que don Quijote ha contratado a Sancho como escudero, lo cual, dentro de los cortos horizontes de promoción social que al labriego se le ofrecen, representa un cierto ascenso en la escala estamental, ya que en aquel momento el

${ }^{43}$ Ibíd., p. 444

44 Ibid., parte $5^{a}$, cap. 5, p. 109.

${ }^{45}$ Ibid., parte $7^{\mathrm{a}}$, cap. 25, p. 328. 
escudero no es el joven noble que sigue al caballero en la guerra, como ocurrió en la Edad Media, sino el hidalgo pobre que sirve de acompañante, o de correveidile y consejero, en casa de algún caballero rico o señor de título -recordemos al personaje de Lazarillo o al escudero vizcaíno del Quijote-, y ejerce por consiguiente un oficio digno y noble, un detalle que no debió de pasar inadvertido para el público del siglo XVII, y que el lector actual no especializado sólo conoce por lo general gracias a la información complementaria que proporcionan las notas a pie de página en las ediciones comentadas. Un escudero, en efecto, nos explica Covarrubias en su Tesoro de la lengua castellana, es:

El hidalgo que lleva el escudo al cavallero, en tanto que no pelea con él; y el que le lleva la lança, que suele ser joven, se llama page de lança. En la paz, los escuderos sirven a los señores de acompañar delante sus personas, asistir en la antecámara o sala; otros se están en sus casas y llevan acostamiento de los señores, acudiendo a sus obligaciones a tiempos ciertos. Oy día más se sirven dellos las señoras; y los que tienen alguna passada huelgan más de estar en sus casas que de servir, por lo poco que medran y lo mucho que les ocupan ${ }^{46}$.

Eran gentes que en la época de Cervantes, y según fray Juan Benito Guardiola, más bien:

...se llaman escuderos por metáphora, por quanto siruen de acompañar los Domingos y fiestas a mugeres, y son como escudo para defenderlas de que no tropiecen por causa de los muy altos chapines, ropas y vestidos de que andan cargadas y demasiadamente atauiadas ${ }^{47}$.

Sancho ha de recibir, a cambio de su trabajo como escudero, un salario igual o superior al que cobraba hasta entonces, o unas mercedes que le ayuden a sacar el pie del lodo ${ }^{48}$, y si tenemos en

${ }^{4}$ Sebastí́n de Covarrubias, Tesoro de la Lengua Castellana o Española, Madrid, Turner, 1979, p. 543.

${ }^{47}$ Fray JUAN BENITO GuARDIOla, Tratado de la nobleza, y de los títulos y ditados que oy día tienen los varones claros y grandes de España, Madrid, 1595, fol. 72.

48 "-Está bien cuanto vuestra merced dice - dijo Sancho-, pero querría yo saber, por si acaso no llegase el tiempo de las mercedes y fuese necesario acudir al de los salarios, cuánto ganaba un escudero de un caballero andante en aquellos tiempos, y si se concertaban por meses, o por días, como peones de albañir.

-No creo yo - respondió don Quijote- que jamás los tales escuderos estuvieron a salario, sino a merced; y si yo ahora te le he señalado a ti en el testamento cerrado que dejé en mi casa, fue por lo que podía suceder» (I, 20, 221-22).

"Voy a parar - dijo Sancho- en que vuesa merced me señale salario conocido de lo que me ha de dar cada mes el tiempo que le sirviere, y que el tal salario se me pague de su hacienda, que no quiero estar a mercedes, que llegan tarde o mal o nunca; con lo mío me ayude Dios» (II, 7, 680-81). 
cuenta las penosas condiciones materiales en que se desenvuelve su existencia, y que el propio texto ilumina de manera suficiente, no es difícil comprender por qué abandona su aldea y a su familia para seguir al hidalgo, un aspecto que también debieron de percibir los lectores de la época: Tras ser apaleado por los yangüeses, nuestro labriego confiesa: «Señor, yo soy hombre pacífico, manso, sosegado, y sé disimular cualquier injuria, porque tengo mujer y hijos que sustentar y criar» (I, 15, 162). Hablando con Teresa, su mujer:

\begin{abstract}
...tengo determinado de volver a servir a mi amo don Quijote, el cual quiere la vez tercera salir a buscar las aventuras; y yo vuelvo a salir con él, porque lo quiere así mi necesidad, junto con la esperanza que me alegra de pensar si podré hallar otros cien escudos como los ya gastados, puesto que me entristece el haberme de apartar de ti y de mis hijos; y si Dios quisiera darme de comer a pie enjuto y en mi casa, sin traerme por vericuetos y encrucijadas, pues lo podía hacer a poca costa y no más de quererlo, claro está que mi alegría fuera más firme y valedera, pues la que tengo va mezclada con la tristeza del dejarte (II, $5,663-64)$.
\end{abstract}

En otra conversación con Teresa:

-Vos me veréis presto conde, o gobernador de una ínsula, y no de las de por ahí, sino la mejor que puede hallarse.

-Quiéralo así el cielo, marido mío, que bien lo habemos menester (I, $52,589-90)$.

Un testimonio que corrobora el morisco Ricote, quien, a cambio del silencio cómplice de Sancho, ofrece a éste «doscientos escudos, con que podrás remediar tus necesidades, que ya sabes que sé yo que las tienes muchas»(II, 54, 1074).

\title{
3. ¿STULTITIAE LAUS O CHOCARRERÍA TRUHANESCA?
}

Y con ello pasamos a examinar otro aspecto de la obra que en su época debió de llamar poderosamente la atención y atraer a numerosos lectores, el de la comicidad del Quijote, que la crítica moderna ha soslayado a menudo, pero que en el momento de la publicación debió de contribuir de manera decisiva a su difusión y éxito ${ }^{49}$, y en la cual, como es sabido, el personaje de Sancho tuvo una responsabilidad de primer orden.

Sobre los conceptos de salario y merced y su papel en la obra, véase CHARLES V. Aubrun, "Sancho Panza, paysan pour de rire, paysan pour de vrai", Revista Canadiense de Estudios Hispánicos, I, 1976, pp. 16-29.

${ }^{49}$ Entre los testimonios más conocidos de este hecho suele citarse profu- 
En efecto, además de llevar a cabo esa labor de reconocimiento que antes hemos comentado, por la cual Sancho Panza quedaba identificado con un cierto tipo social característico del campo castellano -el jornalero o labrador pobre-, al lector español del seiscientos debieron de atraerle sobre todo, igual que a los lectores de hoy, los aspectos cómicos del personaje, y especialmente, a juzgar por los escritos inmediatamente posteriores en que se le recrea o se le cita, su simplicidad e ingenuidad sin límites, su socarronería y actitud burlona, las exigencias y quejas con que a menudo asaetea a su amo, su glotonería, la cobardía y poquedad que a menudo exhibe, su materialismo e inclinación escatológica, sus infundadas ilusiones, y los frecuentes dislates lingüísticos en que incurre, aspectos todos que fueron explotados, aunque a veces de manera muy pedestre, por Alonso Fernández de Avellaneda, cuyo testimonio resultará una vez más fundamental para entender la interpretación de que fue objeto el personaje de Sancho en el momento de editarse la novela.

Respecto a la comicidad de Sancho Panza, debemos señalar, no obstante, una importante diferencia entre la risa que el personaje suscita en el lector actual, y la que pudo provocar cuatro siglos antes: Los rasgos cómicos que hoy apreciamos en Sancho

samente el de Baltasar Porreño, quien en sus Dichos y hechos del señor Rey don Felipe III (1628), señaló cómo en cierta ocasión el monarca, viendo reír exageradamente a un estudiante que leía un libro, comentó a los que le rodeaban: «aquel estudiante, o está fuera de sí, o lee la historia de Don Quijote» (cit. por LEOPOLDo RIUS, Bibliografía, vol. III, p. 12); y el propio Cervantes confirma a menudo la intención cómica de su libro: En el prólogo del Quijote de 1605, el amigo aconseja al escritor: "Procurad también que, leyendo vuestra historia, el melancólico se mueva a risa, el risueño la acreciente» (I, prólogo, 18); y antes de iniciar Sancho su gobierno de la Ínsula Barataria, «Deja, lector amable, ir en paz y enhorabuena al buen Sancho, y espera dos fanegas de risa que te ha de causar el saber cómo se portó en su cargo, y en tanto atiende a saber lo que le pasó a su amo aquella noche, que si con ello no rieres, por lo menos desplegarás los labios con risa de jimia, porque los sucesos de don Quijote o se han de celebrar con admiración o con risa» (II, 44, 982). PETER E. RUSSELL («Don Quijote y la risa a carcajadas», en Temas de "La Celestina" y otros estudios. Del Cid al Quijote, Barcelona, Ariel, 1978, pp. 407-440) ha insistido especialmente en este aspecto, con especial referencia a los lectores ingleses y franceses, aunque ya otros críticos lo habían señalado antes que él y en términos parecidos: Así, Real de la Riva: "A todo esto el pueblo ríe y ríe a carcajadas durante el siglo XVII con las ingeniosas situaciones, ironías, chistes y relatos del estupendo caballero y de su regocijante escudero" (CÉSAR REAL DE LA RIVA, "Historia de la crítica», p. 113); y Alberto Navarro, aunque intente señalar lecturas de más hondo calado en el siglo XVII, admite que, al menos entre los sectores populares, resulta "evidente que don Quijote desfila entre la chacota general en mascaradas y festejos populares, y que junto con Sancho y Dulcinea aparece traído y llevado como personaje pícaro y entremesil, despertando risas» (Alberto NAVARRo GONZÁlez, El "Quijote» español del siglo XVII, Madrid, Rialp, 1964, p. 257). 
tienen un origen que podríamos llamar intrínseco, derivan de sus acciones y dichos, o de las situaciones ridículas en que el personaje se halla envuelto a lo largo de la narración, mientras que en la época en que la novela se editó, la comicidad de Sancho tuvo una importante dimensión de carácter colectivo, que hoy pasa por lo general inadvertida a los lectores no especializados, y que aquí nos interesa recordar.

Como señaló Antonio Vilanova con datos irrebatibles ${ }^{50}$, don Quijote y Sancho parecen encarnar las figuras del loco sabio y discreto y el necio agudo y malicioso, plasmación genial de la doctrina expuesta en el Encomio de la estulticia o Elogio de la locura de Erasmo, un libro que, como otros del humanista holandés, Cervantes conoció bien, a juzgar por las alusiones y paráfrasis presentes en numerosos pasajes de su obra; si bien es este un aspecto que sólo algunos lectores, humanistas avisados, debieron de percibir, en un momento en que aún se prolongaba el éxito de los escritos satíricos, las stultiferae naves y la literatura bufonesca, de moda en el siglo XVI como simple pasatiempo o como arma de crítica social, y en que los bufones y graciosos auténticos desempeñaban un relevante papel en ambientes cortesanos y en las casas de los nobles ${ }^{51}$.

\footnotetext{
${ }^{50}$ Antonio Vilanova, «Erasmo, Sancho Panza y su amigo don Quijote», en Erasmo y Cervantes, Barcelona, Lumen, 1989, pp. 77-125.

${ }^{51}$ Entre la bibliografía dedicada al tema, puede verse BARBARA SWAIN, Fools and Folly during the Middle Ages and the Renaissance, New York, Columbia University Press, 1932, y reimpresión Folcroft, Folcfrot Library Editions, 1976; ENID WELSFORD, The Fool: His Social and Literary History, London, Faber \& Faber, 1935 y 1968 (reimpresión); William Willeford, The Fool and his Scepter. A Study in Clowns and Jesters and their Audience, Evanston, Northwestern University Press, y London, Edward Arnold, 1969; Michel Foucault, Historia de la locura en la época clásica, México, FCE, $2^{\text {a }}$ edic., 1976, 2 vols.; Folie et déraison a la Renaissance. Colloque International tenu en novembre 1973 sous les auspices de la Féderation Internationale des Instituts et Sociétés pour l'Étude de la Renaissance, Bruxelles, Université Libre de Bruxelles, 1976; y MAURICE LEVER, Le sceptre et la marotte. Histoire des fous de cour, Paris, Fayard, 1983. Para España pueden consultarse MARTINE BIGEARD, La folie et les fous littéraires en Espagne, 1500-1650, Paris, Centre de Recherches Hispaniques, 1972, especialmente las pp. 127-133, dedicadas a los bufones de corte; FRANCISco MÁrQuEZ VILlanUEVA, "Un aspect de la littérature du 'fou' en Espagne», en AUGUSTIN REDONDO (ed.), L'Humanisme dans les lettres espagnoles. XIX ${ }^{e}$ Colloque international d'Etudes humanistes, Tours 5-17 juillet 1976, París, J. Vrin, 1979, pp. 233-250; del mismo autor, "Planteamiento de la literatura del loco en España», Sin Nombre, X 4, 1979-1980, pp. 7-25 (es traducción del trabajo anterior); y "La literatura bufonesca o del loco", Nueva Revista de Filología Hispánica, XXXIV, 1985-86, pp. 501-528; AUGUSTIN REDONDO y ANDRÉ ROCHON (eds.), Visages de la folie (1500-1650): Domaine Hispano-italien. Colloque tenu a la Sorbonne les 8 et 9 de mai 1980, Paris, Publications de la Sorbonne, 1981; así como el trabajo clásico de JOSÉ MORENO VILLA, Locos, enanos, negros y niños palaciegos: Gente de placer que tuvieron los Austrias, México, La Casa de España en México,
} 
Aunque despojados de ese papel liberador y subversivo que Erasmo atribuía a la risa y la locura, que sólo se recordaría a principios del siglo XVII en círculos reducidos, la mayoría de lectores de extracción urbana y aristocrática sí debieron de considerar a Sancho, y con él a su señor, como descendientes de una larga saga de personajes bufonescos, que en algunos casos tuvieron una vida exclusivamente literaria, y en otras fueron personas de carne y hueso que vivieron al amparo de los reyes o de los grandes señores, y que con sus inesperadas agudezas o simplicidades, ayudaron a ahuyentar el tedio de las cortes y palacios, y a entretener, e incluso reprender y aconsejar entre burlas y veras, a personajes de condición superior: Son los truhanes, juglares, bufones, chocarreros, hombres de placer y decidores graciosos, locos fingidos o auténticos que, bajo el escudo de una supuesta demencia, hacen las delicias de los auditorios nobles con sus historietas chuscas, con sus disparates e improperios, o descubriendo, entre el regocijo y el sonrojo de los circunstantes, aquellos secretos a voces que, apenas velados por la hipocresía de la vida cortesana, todos conocen y nadie se atreve a revelar ${ }^{52}$. Ya Erasmo comentaba divertido, tratando de los estultos:

Juzguen otros de si habrá banquete completo sin mujeres; lo que sí consta es que ninguno resulta agradable sin el condimento de la estulticia. Tanto es así, que si falta uno que mueva a la risa con necedad verdadera o simulada, se pagará a algún bufón o se invitará a algún gorrón ridículo que con dicharachos risibles, es decir, estultos, ahuyente de la reunión el silencio y la tristeza [...].

¿Y qué diréis si afirmo que incluso gozan de la gracia de los máximos reyes, de suerte que algunos no saben comer, ni andar, ni pasar una hora sin ellos? Muy a menudo anteponen estos tontilocos a sus aburridos sabios, a los cuales algunas veces mantienen por pura vanidad ${ }^{53}$.

Según la definición de Covarrubias, el truhán es:

El chocarrero burlón, hombre sin vergüença, sin honra y sin respeto; este tal, con las sobredichas calidades, es admitido en los palacios de los reyes y en las casas de los grandes señores, y tiene licencia de dezir lo que se le antojare, aunque es verdad que todas sus libertades las viene a pagar, con que le maltratan de cien mil maneras y todo lo sufre por su gula y avaricia, que come muy buenos bocados, y quando le parece se retira con mucha hazienda ${ }^{54}$.

1939; y el más reciente de FERNANDo J. Bouza ÁlVAREZ, Locos, enanos y hombres de placer en la Corte de los Austrias. Oficio de burlas, Madrid, Temas de Hoy, 1991.

${ }_{52}$ Véase la bibliografía citada en la nota precedente.

${ }^{53}$ ERASMO DE RotTERdAM, Elogio de la locura, caps. 18 y 36, Madrid, EspasaCalpe, Col. Austral, $4^{\mathrm{a}}$ edic., 1969 , pp. 43 y 70.

${ }^{54}$ Sebastián De CovarRubias, Tesoro de la Lengua Castellana, edic. cit., p. 981. 
El chocarrero, según el mismo autor, es:

El hombre gracioso y truhán, quasi iocarrero, a ioco, porque es hombre de burlas, y con quien todos se burlan; y también se burla él de todos, porque con aquella vida tienen libertad y comen y beven y juegan; y a vezes medran más con los señores que los hombres honrados y virtuosos y personas de letras. Dizen que los palacios de los príncipes no pueden passar sin éstos ${ }^{55}$.

Mateo Alemán explica que los señores son propensos a «dar antes a un truhán el mejor de sus vestidos que a un virtuoso el sombrero desechado", aunque a continuación admite: "Necesario es y tanto suele a veces importar un buen chocarrero como el mejor consejero" ${ }^{56}$ :

Y éstos, acontecen ocasiones en que suelen valer mucho, advirtiendo, aconsejando, revelando cosas graves en son de chocarrerías, que no se atrevieran cuerdos a decirlas con veras.

Graciosos hay discretos, que dicen sentencias y dan pareceres que no se humillaran sus amos a pedirlos a otros de sus criados, aunque les importaran mucho y fueran ellos grandísimos estadistas para poderlos aconsejar, ni lo consintieran dellos, por no confesarse ignorantes a sus inferiores o que saben menos que ellos ${ }^{57}$.

\section{Y Saavedra Fajardo:}

... se introdujo la asistencia a las mesas de los príncipes de bufones, de locos y de hombres mal formados. Los errores de la naturaleza y el desconcierto de los juicios son sus divertimientos. Se alegran de oír alabanzas disformes que, cuando las excuse la modestia, como dichas de un loco, las aplaude el amor propio; y hechas las orejas a ellas, dan crédito después a las de los aduladores y lisonjeros ${ }^{58}$.

Varios personajes de la obra, y especialmente los del estamento superior, hastiados de diversiones monótonas y ceremonias insípidas, van a tratar de utilizar a Sancho y a don Quijote como un antídoto contra el aburrimiento, transformándolos por unos días en dos bufones con un inacabable repertorio de locuras, ocurrencias chuscas y divertidas actuaciones a cuestas. Y, en efecto, en las ventas que visitan en el volumen de 1605, y sobre todo en la segunda parte, durante su estancia en Barcelona, y especialmen-

\footnotetext{
${ }^{55}$ Ibíd., pág. 437.

56 MATeo Alemán, Guzmán de Alfarache, $2^{\mathrm{a}}$ parte, lib. I, cap. 2, en La novela picaresca española, edic. de Ángel Valbuena Prat, Madrid, Aguilar, $7^{a}$ edic., 1986, 2 vols., vol. I, p. 489.

57 Ibíd., p. 491.

58 DIEgO SAAVEDRA FAJARDO, Idea de un príncipe politico cristiano representada en cien empresas, en Obras, Madrid, Atlas, 1947 (BAE, 25), p. 197.
} 
te en el palacio ducal y en el desempeño de su fingido gobierno, en que la acumulación de elementos bufonescos y carnavalescos llega al máximo, Sancho, junto a don Quijote, es el truhán chocarrero al que constantemente se coloca en el disparadero para provocar la risa de quienes le tratan, un aspecto de su personaje que el propio Cervantes se encarga de insinuar ${ }^{59}$, y que, ya antes de la publicación de la segunda parte del Quijote, debió de llamar la atención de los lectores, incluido Fernández Avellaneda, quien explota esa vertiente de manera reiterada a lo largo de su obra, si bien en ella están ausentes la ambigüedad y reversibilidad características del personaje cervantino, capaz de burlarse de sus burladores, y de lograr que la estulticia feliz y clarividente, de raíz erasmiana, llegue a ser la verdadera lección que se desprende del libro, como veremos después ${ }^{60}$.

En el Quijote de Avellaneda, en efecto, y ya en uno de sus primero capítulos, don Álvaro Tarfe nos advierte acerca de las aptitudes que Sancho y su amo poseen para las actividades truha-

${ }^{59}$ Ya a la puerta del palacio ducal, doña Rodríguez dirige a Sancho estas palabras: "Hermano, si sois juglar - replicó la dueña-, guardad vuestras gracias para donde lo parezcan y se os paguen, que de mí no podréis llevar sino una higa» (II, 31, 881). Y don Quijote, como si presintiera el papel que su escudero podría desempeñar en los siguientes capítulos de la novela, le reprende diciendo: «Dime, truhán moderno y majadero antiguo: ¿parécete bien deshonrar y afrentar a una dueña tan veneranda y tan digna de respeto como aquella? [...] No, no, Sancho amigo: huye, huye destos inconvinientes, que quien tropieza en hablador y en gracioso, al primer puntapié cae y da en truhán desgraciado" (II, 31, 883-84).

${ }^{60}$ El tema ha sido abordado, entre otros, por ANTHONY J. CLOSE, "Sancho Panza: Wise Fool», Modern Language Review, LXVIII, 1973, pp. 344-357, quien estudia el papel del escudero, no sólo como bufón gracioso, especialmente en casa de los Duques, sino también como loco clarividente, sentencioso y sabio en la segunda parte de la obra, así como su relación con los simples y graciosos del teatro, bufones y locos palaciegos muchos de ellos, con los que Sancho, como indicamos después, también se halla emparentado. Pueden verse, además, los artículos de Jean Canavaggio, "Las bufonadas palaciegas de Sancho Panza", en Cervantes. Estudios en la víspera de su centenario, Kassel, Reichenberger, 1994, 2 vols., vol. I, pp. 237-258; y FrANCISCO MÁrQUEZ VIllaNUEVA, «La locura emblemática en la segunda parte del Quijote», en Michael D. McGaHA (ed.), Cervantes and the Renaissance, pp. 87-112, reproducido en Trabajos y días cervantinos, Alcalá de Henares, Centro de Estudios Cervantinos, 1995, pp. 23-58; y, sobre todo, el reciente y clarificador trabajo, ya citado, de JAMES IFFLAND (De fiestas y aguafiestas, pp. 329 y ss. y 439 y ss.), quien señala una importante distinción entre la actuación de Sancho y su amo en las ventas de la primera parte, y en Barcelona con don Antonio Moreno, por un lado, y en los episodios que tienen lugar en Aragón, en el palacio ducal, de otro: En el primer caso, la risa que provocan nuestros personajes es una risa colectiva, de raíz carnavalesca, en que participa el pueblo llano, a veces activamente, mientras que en el segundo, la risa y la fiesta han sido confiscadas, encerradas entre las paredes del palacio para el disfrute exclusivo de los nobles y sus allegados (ibíd., pp. 439 y 481 y ss.). 
nescas: «Por Dios, que si el rey de España supiese que este entretenimiento había en este lugar, que aunque le costase un millón, procurara tenerle consigo en su casa ${ }^{61}$. En el juego de sortija celebrado en Zaragoza, don Quijote aparece ridículamente vestido, aunque:

...no es cosa nueva en semejantes regocijos sacar los caballeros a la plaza locos vestidos y aderezados y con humos en la cabeza de que han de hacer suerte, tornear, justar y llevarse premios, como se ha visto algunas veces en la ciudades principales y en la misma Zaragoza ${ }^{62}$.

Don Carlos y sus amigos querrían que Sancho y su amo les acompañaran para triunfar con ellos en Madrid, presentando ante la corte a tan extraña pareja, como explica el secretario de aquél, cuando propone «que demos orden, si a vuesa merced le parece, que pieza tan singular y que es tan de rey, entre por nuestra industria en la corte para regocijarla ${ }^{63}$. Finalmente, mientras su amo es encerrado en la casa del Nuncio en Toledo, para procurar su curación, Sancho se queda en Madrid, en casa del Archipámpano, como bufón permanente, para regocijo del señor y sus amigos, con lo cual, en lugar de conquistar ínsulas y penínsulas, todas las aventuras del labriego habrán consistido en:

...haber sido terrero de desgracias en Ateca, blanco de desdichas en Zaragoza, recreación de pícaros en la cárcel de Sigüenza, irrisión de Alcalá, y últimamente mofa y escarnio desta corte ${ }^{64}$.

\section{UN VILLANO TOSCO Y SIMPLE}

Pero, junto a la vertiente bufonesca de los personajes que hemos comentado, para el lector del siglo XVII, como ya indicábamos en páginas anteriores, el personaje de Sancho debió de ser ante todo el prototipo del labriego simple y bobo, socarrón y bellaco si conviene, aficionado a la comida y al vino, que hace reír a todos con sus dichos peculiares, sus dislates léxicos, su conducta zafia, o con su ingenuidad y su malicia. Tal personaje, el labriego simple, formaba parte de una larga tradición literaria que arranca de la Edad Media, que cristaliza sobre todo, con notable éxito, en el teatro del Renacimiento y el Barroco, desde Juan del Encina, Torres Naha-

${ }^{61}$ Alonso Fernández de Avellaneda, El ingenioso hidalgo don Quijote de la Mancha, edic. cit., parte $5^{\text {a }}$, cap. 2 , p. 78

${ }^{62}$ Ibid., parte $5^{\text {a }}$, cap. 11, p. 166.

${ }_{63}$ Ibíd., parte $6^{\mathrm{a}}$, cap. 13 , p. 193.

${ }^{64}$ Ibíd., parte $7^{\text {a }}$, cap. 35 , p. 441. 
rro o Lope de Rueda, hasta Lope de Vega y los dramaturgos de su escuela, como Tirso o Calderón ${ }^{65}$, y que sin duda tuvieron muy presente los lectores de la época, no sólo porque conocieran a tales personajes a través de las representaciones teatrales, sino porque el tipo cómico del labrador formaba parte de una vieja tradición oral muy viva entonces entre gentes de toda condición.

Al menos un par de críticos $^{66}$ han señalado la relación que Sancho Panza guarda con los rústicos y bobos del teatro cómico anterior a él, y han seleccionado los numerosos detalles coincidentes que es posible descubrir entre su conducta y la de tales personajes: la gula, el orgullo, la astucia, la estupidez, la ingenuidad o la socarronería. Conviene, sin embargo, recordar que en aquellos albores de la Edad Moderna sólo un reducidísimo porcentaje de la población tiene acceso a lo que en un sentido restrictivo solemos llamar cultura, es decir, la cultura escrita y académica, o a las representaciones teatrales de los autores que acabamos de citar, restringidas en aquel momento a un ámbito urbano, a veces exclusivamente aristocrático; en tanto que la otra cultura cotidiana, oral y anónima, la de los cuentos, refranes y chascarrillos, gozaba de enorme vitalidad; y ello es tan cierto, que, sin temor a exagerar, podemos decir que el auténtico bagaje cultural de las gentes del Siglo de Oro no estaba formado por los libros de pastores y las odas de Fray Luis, o por las églogas de Juan del Encina y las comedias de Lope, sino por los proverbios, los romances, las canciones nupciales, de amor o de trabajo, y especialmente por los chistes, las consejas y los cuentecillos que ayudaban a sobrellevar las veladas junto al fuego en el invierno, o al fresco durante el verano, es decir, por una cultura de carácter eminentemente oral ${ }^{67}$,

${ }^{65}$ Véase William S. HendrIx, Some Native Comic Types in the Early Spanish Drama, Columbus, Ohio State University, 1924; y NOËL SALOMON, Lo villano en el teatro del Siglo de Oro, Madrid, Castalia, 1985, pp. 17-149.

${ }_{66}$ W. S. HENDRIX, "Sancho Panza and the Comic Types of the Sixteenth Century», en Homenaje ofrecido a Menéndez Pidal. Miscelánea de estudios lingüísticos, literarios e históricos, Madrid, Hernando, 1925, 3 vols., vol. II, pp. 485-494; y FRANcisco Márouez VillanueVa, "La génesis literaria de Sancho Panza», en Fuentes literarias cervantinas, Madrid, Gredos, 1973, pp. 20-94.

${ }^{67}$ Véase MAXIME CHEVALIER, Folklore y literatura. El cuento oral en el Siglo de Oro, Barcelona, Crítica, 1978; Tipos cómicos y folklore (Siglos XVI-XVII), Madrid, Edi-6, 1982; Traditions populaires et diffusion de la culture en Espagne (XVI ${ }^{e}-X V I I^{e}$ siècle), Bordeaux, Presses Universitaires de Bordeaux, 1982; Cuento tradicional, cultura, literatura (siglos XVI-XIX), Salamanca, Universidad de Salamanca, 1999; y J. L. Alonso HeRnÁndez (ed.), Literatura y folklore. Problemas de intertextualidad. Actas del $2^{\circ}$ Symposium Internacional del Departamento de Español de la Universidad de Groningen, 28, 29 y 30 de octubre de 1981. Salamanca, Ediciones de la Universidad de Salamanca, 1983; así como las recopilaciones de cuentecillos de la época llevadas a cabo por MAXIME CHEVALIER, Cuentecillos tradicionales en la 
presente por doquier en la obra de Cervantes $^{68}$, y en la que nuestro personaje es consumado maestro ${ }^{69}$ : Sancho, en efecto, no sabe leer ni escribir ${ }^{70}, y$, sin embargo, qué enorme caudal de sabiduría se advierte en sus palabras, especialmente cuando le vemos recitar o recordar la historia de Calaínos (II, 9, 698), la de los Infantes de Lara (II, 60, 1118), y otros «romances españoles que andan en boca de las gentes y de los muchachos por esas calles» (II, 26, 846); cuando Cervantes nos lo describe contando a su amo cuentos, como el de la Pastora Torralba, que explica durante la angustiosa espera que precede al encuentro con los terribles batanes (I, 20, 213 y ss.); o cuando ensarta sus estupendos refranes, y se disculpa ante don Quijote con estas sabias palabras:

¿A qué diablos se pudre de que yo me sirva de mi hacienda, que ninguna otra tengo, ni otro caudal alguno, sino refranes y más refranes? $\mathrm{Y}$ ahora se me ofrecen cuatro que venían aquí pintiparados, o como peras en tabaque (II, 43, 977).

España del Siglo de Oro, Madrid, Gredos, 1975; Cuentos españoles de los siglos XVI y XVII, Madrid, Taurus, 1982; Cuentos folklóricos en la España del Siglo de Oro, Barcelona, Crítica, 1983.

68 Véase MAXIME CHEvalier, "Literatura oral y ficción cervantina», Prohemio, V 2-3, 1974, pp. 161-196; del mismo autor, "Huellas del cuento folklórico en el Quijote», en MANUEL CRIADO DE VAL (ed.), Cervantes, su obra y su mundo. Actas del I Congreso Internacional sobre Cervantes, Madrid, Edi-6, 1981, pp. 881-893; ARDIS L. NELSON, "Función y pertinencia del folklore en el Quijote», Anales Cervantinos, XVII, 1978, pp. 41-51; LouIS COMBET, "Folklore y estructura en la obra de Cervantes", en el volumen, ya citado, Literatura y folklore. Problemas de intertextualidad, ed. de J. L. AlONSO HERNÁNDEZ, Salamanca, Universidad de Salamanca, 1983, pp. 149-160; y VSEVOLOD BAGNó, «El tonto de los cuentos populares como arquetipo folklórico del Quijote», Anales Cervantinos, XXVIII, 1990, pp. 237-241.

${ }_{69}$ Sobre la educación y cultura del personaje, véase FEDERICo SÁNCHEZ EsCRIBANO, «Sancho Panza y la cultura popular. Un aspecto de sociología cervantina», Asomante, III, 1948, pp. 33-40; MAXIME CHEVAliER, "Sancho Panza y la cultura escrita», en Dian FoX, HARRY Sieber y Robert T. Horst (eds.), Studies in Honor of Bruce W. Wardropper, Newark, Delaware, Juan de la Cuesta, 1989, pp. 67-73; DOMINICK Finello, "Genealogía rústica de Sancho Panza», en Actas del II Coloquio Internacional de la Asociación de Cervantistas. Alcalá de Henares, 6-9 de noviembre de 1989, Barcelona, Anthropos, 1991, pp. 493-499; y DOROTHY THARPE, «The Education of Sancho Panza as Seen in his Personal References», Modern Language Journal, XLV, 1961, pp. 244-248, que se ocupa del carácter, más que de la educación de Sancho, al que examina como un villano y cristiano viejo de temperamento pacífico.

70 «Ni sé leer ni escrebir»(I, 10, 114). «Yo no sé leer ni escribir, puesto que sé firmar» (II, 36, 931). "Letras, pocas tengo, porque aun no sé el abecé» (II, 42, 968). «Bien sé firmar mi nombre, que cuando fui prioste en mi lugar aprendí a hacer unas letras como de marca de fardo, que decían que decía mi nombre» (II, $43,976)$. En otro momento, sin embargo, admite: "Y esto lo diera firmado de mi nombre si supiera firmar» (II, 51, 1047). 
Pero esas dos culturas, distintas en apariencia, a las que hemos aludido, la popular y la escrita, no permanecen divorciadas entre sí, ya que, aparte de otros puntos de contacto que es posible advertir entre una y otra, la tradición literaria oral fue un importante venero de inspiración de numerosos autores, que encontraron en la canción tradicional o en los relatos folklóricos una sustanciosa fuente de motivos y de anécdotas para entretejer en sus escritos, y en tal terreno también nos ofrece Sancho un modelo inigualable.

La conclusión que nos interesa extraer de todo ello, y la premisa de la que partimos, es que los lectores de la época debieron de relacionar al personaje de Sancho, más que con una fuente literaria escrita o culta, como era el teatro de la época, con modelos folklóricos presentes en las tradiciones de tipo carnavalesco ${ }^{71}$, en el refranero ${ }^{72}$, y, sobre todo, en la multitud de chistes, cuentos, anécdotas y chascarrillos que entonces salpicaban la conversación, y en muchos de los cuales el protagonista suele ser el labriego prototípico, simple y agudo, malicioso y bobo, muy similar al que Cervantes nos presenta en su novela ${ }^{73}$.

La bobería de los campesinos y aldeanos, convertida en un motivo común de cuentos y chascarrillos, es, en efecto, un recurso cómico casi universal, que en nuestro Siglo de Oro tuvo enor-

${ }^{71}$ La cuestión de las raíces carnavalescas de la obra cervantina, señaladas por MiJail BaJtín (La cultura popular en la Edad Media y el Renacimiento. El contexto de François Rabelais, Madrid, Alianza Universidad, 1987, pp. 26-27) ha dado lugar a la aparición de interesantes estudios en las dos últimas décadas, entre los que destacan los de AUGUSTIN REDONDO, especialmente "Tradición carnavalesca y creación literaria: Del personaje de Sancho Panza al episodio de la ínsula Barataria en el Quijote», Bulletin Hispanique, LXXX, 1978, pp. 39-70, reproducido en Otra manera de leer El Quijote. Historia, tradiciones culturales y literatura, Madrid, Castalia, 1997, pp. 191-204; «El personaje de Don Quijote: tradiciones folklórico-literarias, contexto histórico y elaboración cervantina», Nueva Revista de Filología Hispánica, XXIX, 1980, pp. 36-59, reproducido en Otra manera de leer El Quijote, pp. 205-230; "El Quijote y la tradición carnavalesca», Anthropos, 98-99, 1990, pp. 93-98; y "La tradición carnavalesca en el Quijote», en JAVIER HUERTA CALvo (ed.), Formas carnavalescas en el arte y la literatura, Barcelona, Serbal, 1989, pp. 153-181; MANUEL DURÁN, "El Quijote a través del prisma de Mikhail Bakhtine: carnaval, disfraces, escatología y locura», en MichaEL D. McGAHA (ed.), Cervantes and the Renaissance. Papers of the Pomona College. Cervantes Symposium, november, 16-18, 1978, Easton, Pennsylvania, Juan de la Cuesta, 1980, pp. 87-112; y recientemente JAMES IFFLAND, De fiestas y aguafiestas, passim.

72 MAURicio Molho, "Raíz folklórica de Sancho Panza», en Cervantes: Raíces folklóricas, Madrid, Gredos, 1976, pp. 249 y ss.

${ }^{73}$ Véase MAXIME CHEVALIER, "Literatura oral y ficción cervantina», pp. 191 y ss.; del mismo autor, Tipos cómicos y folklore, pp. 126-141; MAURICIO MOLHO, "Raíz folklórica de Sancho Panza», pp. 217-336; y MoniQue JOLY, «La construction du personnage de Sancho: Du conte traditionnel aux apophtegmes», Les Langues Néo-Latines, 295, 1995, pp. 87-96. 
me aceptación, a juzgar por el nutrido corpus de anécdotas y cuentecillos que han llegado hasta nosotros. Los protagonistas de estos sencillos relatos pueden ser los habitantes de algún lugar conocido por su proverbial simplicidad:

Como los de cierto pueblo, que untaron un banco con manteca, para que diese de sí y cupiese más gente. Y sí cupo, mas fue porque se quitaron los capotes $^{74}$.

Un ejemplo de simpleza y brutalidad asombroso lo protagonizan los vecinos de Almudévar, una aldea situada entre Huesca y Zaragoza, donde el herrero cometió un delito que merecía la horca, lo cual supondría un grave inconveniente para el pueblo, al faltar un artesano tan necesario entre gente dedicada a la labranza, por lo que sus habitantes, aconsejados por Pedro Zaputo, personaje de un ingenio proverbial, tomaron esta sabia decisión:

...que pues había dos tejedores y no más de un herrero, ahorcasen al un tejedor, que bastaba el otro, y dejasen al herrero, que les haría falta ${ }^{75}$.

En la colección de cuentos de Juan de Arguijo leemos, a propósito de los labradores de Lucena:

Mandaron hacer unos labradores de Lucena a un escultor de Córdoba un Cristo para su cofradía. Preguntábales el artífice si había de ser muerto o vivo. No supieron resolverse, y en caso de duda, le dijeron que lo hiciese vivo, que si así no contentase, allá lo matarían ${ }^{76}$.

${ }^{74}$ FRANCISCO LÓPEZ DE ÚBEDA, La Pícara Justina, lib. III, cap. $2^{\circ}$, en La novela picaresca española, edic. cit., vol. I, p. 1067. También Gonzalo Correas recoge alusiones proverbiales referentes a "los bobos de Sando" y «los bobos de Pedernal», que comenta así: «A los destos lugares atribuyen los cuentecillos vulgares de simplezas, por darles matraca, como: que untaron la viga para que creciese, y otros tales» (GONZALO CORREAS, Vocabulario de refranes y frases proverbiales, edic. de Louis Combet, Bordeaux, Université de Bordeaux, Institut d'Études Ibériques et IbéroAméricaines, 1967, p. 223). Ambos textos pueden verse en MAXIME CHEvaliER, Cuentos folklóricos, p. 160.

${ }^{75}$ GonZalo CoRREAS, Vocabulario de refranes, edic. cit., p. 44. El mismo cuento aparece recogido, entre otras recopilaciones de la época, en MELCHOR DE SANTA CRUZ, Floresta española, parte IV, cap. VI, núm. 6, edic, de Maximiliano Cabañas, Madrid, Cátedra, 1996, p. 301; y GARIBAY, Cuentos, en Sales españolas o agudezas del ingenio nacional, edic. de Antonio Paz y Meliá, Madrid, Atlas, 1964 (BAE, 176), p. 213. Lo reproduce MAXIME Chevalier, Cuentos folklóricos, p. 284; y Cuentecillos, pp. 96-97.

${ }_{76}$ Cuentos recogidos por Juan de Arguijo y otros, edic. de Beatriz Chenot y Maxime Chevalier, Sevilla, Diputación Provincial de Sevilla, 1979, p. 62, núm. 102; también en MAXIME CHevalier, Cuentos folklóricos, p. 176. 
En otros casos, el protagonista de estos cuentos acostumbra a ser el aldeano simplón, Juan tonto o Perico el bobo, prototipo de palurdo necio, capaz de llegar en su ignorancia a extremos inverosímiles, y de arrancar inmediatamente la risa del auditorio con sus tonterías, como ocurre con el aldeano que conducía una recua de seis burros y se alarmó al comprobar que le faltaba uno, porque al contarlos se olvidaba del asno en que cabalgaba, de donde nació lo de «La asnada de Gálvez», frase proverbial que anota Gonzalo Correas ${ }^{77}$. Luis de Pinedo recoge en su Libro de chistes la anécdota del labriego simple -en otras ocasiones se trata de un criado vizcaíno- que estando en la iglesia cree que las palabras que el cura pronuncia en la homilía van dirigidas a él:

En un lugar de tierra de Campo, que dicen la Población, un echacuervo había mandado, so pena de excomunión, que todos viniesen al sermón; y estando predicando, había tomado por tema lo de Job: Quid est homo, etc., y estando proponiendo su tema y declarándole en romance, un vecino del pueblo había llevado a echar unas yeguas que tenía al prado, y en esto, en tiempo que el predicador, declarando el tema, decía: - Hombre, ¿quién sois? ¿De dónde venís?-. Pensando el otro que se lo preguntaba a él porque venía tarde, dijo: - Señor, Pero González soy, que vengo de echar las yeguas al prado-. Dijéronle los que estaban cabo él: -Callá, cuerpo de tal, que es la tema que ha tomado- . Respondió él: - $\mathrm{Si}$ es tema que ha tomado, tómela con él y con la puta que le parió, y no conmigo-. Y no le podían hacer entender que era tema de sermón ${ }^{78}$.

Otro caso parecido de simplicidad lo recoge Juan de Arguijo en su colección de cuentos:

En el mismo lugar, estando unos villanos en la siega, tenían un cántaro de agua entre unas cañas verdes, adonde llegado un muchacho y viendo su rostro en el agua, volvió a decir a los segadores que estaba un muchacho dentro del cántaro. Asombrados, dejaron la obra y acudieron a verlo. El primero que llegó, viéndose también en el agua, volvió a los demás diciendo:

- $Y$ Y aun con barbas, juro a Dios! ${ }^{79}$

77 «Llevaba siete asnos de recua, e iba caballero en uno; pasando por un lugar, porque alguno no se le perdiese, contólos, y no hallando más de seis, porque no contaba el en que iba, comenzó a preguntar por él, dando señas, hasta que los otros con risa le dijeron que iba caballero en él; y quedó por refrán "La asnada y bobería de Gálvez" en Aragón" (GonZalo CoRREAS, Vocabulario de refranes, edic. cit., p. 181). Lo recoge MAXIME Chevalier (Cuentos folklóricos, p. 163; y Cuentecillos, pp. 174-175), quien incluye otras versiones del cuento, entre ellas la breve referencia que aparece, en boca de Altisidora, en la segunda parte del Quijote (II, 57).

${ }^{78}$ LUIS DE PINEDo, Libro de chistes, en Sales españolas, edic. cit., p. 107.

79 Cuentos recogidos por Juan de Arguijo, edic. cit., p. 61, núm. 100; y en MAXIME Chevalier, Cuentos folklóricos, p. 173. 
El mismo autor refiere esta otra anécdota, en que a la bobería no le faltan sus puntas de malicia, un aspecto sobre el que hemos de volver:

Diéronle a un muchacho una olla con carne que llevase al campo a unos gañanes. Comióse la carne, y preguntado por ella, dijo llorando: caldo ${ }^{80}$

-Tropecé, y derramóseme toda la carne y no pude coger más que el

$\mathrm{Y}$ aun añadiremos otro cuento protagonizado por un labriego simple y malicioso, recogido también por Juan de Arguijo:

Levantóse de confesar un aldeano y díjole a otro amigo suyo:

- Por Dios, compadre, que de milagro no me ha sacado el cura de la boca lo que nos pasó la otra noche. Preguntóme si había hurtado algo, y respondíle: "¿Qué quiere su reverencia que haiga hurtado?». Respondió: "Algún cesto de uvas o de membrillos». Por Dios, si dice de peras, que me lo saca lindamente, mas como dijo unos membrillos, no hablé más de la cosa que del colodrillo ${ }^{81}$.

En fin, hay ocasiones en que la simplicidad viene empedrada de hinchazón y vanidad -imitación paródica del orgullo nobiliario-, como en este cuento que recoge Gaspar Lucas Hidalgo, en que los labradores remedan grotescamente la actitud de los caballeros que intervenían en los festejos taurinos, una actividad que entonces estaba reservada a la nobleza:

Corríanse toros en cierta villa de España, y antojóseles a unos labradores que venían de cavar sus viñas, pasar por medio del coso poco antes que soltasen el toro, caballeros en sus jumentillos y las azadas al hombro. En esta sazón soltaron el toro, y como la gente les dijese a voces que se apartasen a un lado porque estaba el toro fuera, uno dellos, muy tieso y haciendo piernas en su borriquillo, dijo: «Eso queremos los de a caballo» $^{82}$.

Melchor de Santa Cruz, por su parte, recoge en su Floresta varios cuentecillos protagonizados por labriegos que provisionalmente desempeñan el cargo de alcaldes de su lugar, y a los que el deseo de aparentar una cultura y unas formas de expresión que no dominan, les lleva, como a nuestro Sancho Panza en más de una ocasión, a cometer dislates en los que la comicidad viene en ocasiones aumentada por el vano orgullo que el labriego exhibe:

${ }^{80}$ Ibid., p. 202, núm. 483; y Maxime Chevalier, Cuentos folklóricos, p. 177

81 Ibíd., p. 89, núm. 177; y MAXIMe Chevalier, Cuentos folklóricos, p. 383.

82 GaSPaR LuCAS Hidalgo, Diálogos de apacible entretenimiento, en Curiosidades bibliográficas. Colección escogida de obras raras de amenidad y erudición, edic. de Adolfo de Castro, Madrid, Atlas, 1950 (BAE, 36), p. 313. 
Un hombre cometió un delito en un lugar deste reino, y siendo preso en otro lugar cerca de allí, pidiéndole el alcalde que le remitiesen para hacer justicia dél, decía: "Adonde se hace el deleite, allí ha de ser remitido» ${ }^{83}$

En otra aldea, el alcalde demuestra su apego al cargo con las siguientes palabras:

Quiriendo decir el mismo, un año que le cupo por suerte de ser regidor del pueblo, que por habello hecho bien merecía que fuese regidor perpetuo, dijo: "Perfeto regidor había yo de ser, que no año por suerte» ${ }^{84}$.

En fin, un campesino, "Siendo alcalde, queriendo castigar a uno conforme a las leyes del reino [o pragmática], dijo: "Traigan la flemática" ${ }^{85}$. Y otro, "Preguntándole que aquella pena pecuniaria a quién se había de aplicar, respondió: "Para la cámara y físico de su alteza" ${ }^{86}$.

Tras leer estas historias no es difícil descubrir numerosas coincidencias entre la simpleza y la credulidad de Sancho Panza y la de los villanos tontos que aparecen en los cuentos: El escudero de don Quijote, en efecto, se nos presenta ya desde el comienzo del libro como un hombre de "poca sal en la mollera», según dice el narrador, o con palabras del hidalgo: "Asno eres, y asno has de ser, y en asno has de parar cuando se te acabe el curso de la vida" (II, 28, 866). El propio Sancho, aunque capaz para alcanzar un gobierno, se considera a sí mismo «zafio y villano» (I, 23, 249), y declara: «Sí, que para preguntar necedades y responder disparates no he menester yo andar buscando ayuda de vecinos» (II, 22, 813). En otra ocasión: «Señor mío, yo confieso que para ser del todo asno no me falta más de la cola»(II, 28, 867); o también: "soy un hombre que tengo más de mostrenco que de agudo" (II, $51,1046)$. Por ello, es lícito suponer que la similitud entre el labriego cervantino y los bobos del folklore debió de ser advertida de manera unánime por los lectores contemporáneos de Cervantes, que traerían de inmediato a su memoria a tales personajes, sobre todo al observar cómo Sancho, igual que en los cuentecillos citados, cambia «dictado» por litado (I, 21, 234), «alta y soberana señora» por "alta y sobajada señora» (I, 26, 296), «dócil» por fócil (II, 7, 679), "fiscal» por friscal (II, 19, 786), o confunde el bálsamo de Fierabrás con «dos tragos de aquella bebida del feo Blas»

${ }^{83}$ MELChOR DE SANTA CRUZ, Floresta española, parte IV, cap. I, núm. 10, edic. cit., p. 281.

${ }_{84}$ Ibíd., núm. 11.
${ }^{85}$ Ibíd., núm. 12.
${ }^{86}$ Ibíd., núm. 13, p. 282. 
$(\mathrm{I}, 15,161)^{87}$; o cuando, en otras ocasiones, cree a pies juntillas que va a ser gobernador de una ínsula, que el bálsamo de Fierabrás tiene efectos milagrosos, que Dorotea es realmente la princesa de Micomicón, cuyo reino ha sido usurpado por un terrible gigante, o que su amo será coronado emperador y a él le concederán el gobierno de una ínsula. En fin, igual que ocurre con el protagonista de aquellas anécdotas y cuentecillos protagonizados por labriegos, la simplicidad y necedades de Sancho provocan entre quienes le conocen o le tratan reacciones de "gusto" (I, 26, 297 y I, 52, 588) y «admiración» (I, 29, 337 y I, 50, 573), especialmente cuando el fingido escudero quiere hacerse cortesano, y «acaba su razón con despeñarse del monte de su simplicidad al profundo de su ignorancia» (II, 22, 720), o cuando es capaz de dar por cierta la burla que el mismo hubo de inventar, como ocurre en el palacio de los Duques, cuando:

\begin{abstract}
...de lo que más la duquesa se admiraba era que la simplicidad de Sancho fuese tanta, que hubiese venido a creer ser verdad infalible que Dulcinea del Toboso estuviese encantada, habiendo sido él mesmo el encantador y el embustero de aquel negocio (II, 34, 912).
\end{abstract}

Tras lo dicho, parece claro que el lector del siglo XvII debió de ver en el escudero que acompaña a don Quijote a un labrador simple, similar a los protagonistas de aquellos cuentecillos que andan en boca de todos; y si nos fijamos ahora en las primeras imitaciones de que fue objeto nuestro personaje, o los primeros textos que se refieren a él, descubrimos, en efecto, que las referencias al origen rústico y a la simplicidad de Sancho Panza son prácticamente unánimes ${ }^{88}$. En el anónimo Discurso de la viuda de veinticuatro maridos, un personaje comenta:

\footnotetext{
87 Véase Amado Alonso, "Las prevaricaciones idiomáticas de Sancho Panza», Nueva Revista de Filología Hispánica, II, 1948, pp. 1-20; y ÁNGEL ROSENBLAT, La lengua del "Quijote», Madrid, Gredos, 1971, pp. 35 y ss.; así como las precisiones de Monique JOLY, "Ainsi parlait Sancho Panza», Les Langues Néo-Latines, LXIX 215, 1975, pp. 3-36, reproducido en Études sur Don Quichotte, Paris, Publications de la Sorbonne, 1996, pp. 257-297.

${ }^{88}$ Para algunas lecturas, imitaciones e interpretaciones del personaje de Sancho, y el Quijote en general, en la España del siglo XVII, pueden verse los trabajos de LEOPOldo RiUs, Bibliografía, vol. III, pp. 2 y ss.; EMILIo CotaRElo y MORI, "Sobre las imitaciones castellanas del Quijote», discurso de recepción del autor en la Real Academia Española, 1900, en Estudios de Historia Literaria de España, Madrid, Imprenta de la Revista Española, 1901, vol. I, pp. 71-100; MIGUEL HERRERO GARCÍA, Estimaciones literarias del siglo XVII, Madrid, Voluntad, 1930, cap. V, especialmente las pp. 375-384, referentes a Sancho Panza; CÉSAR REAL DE LA RIVA, «Historia de la crítica», pp. 107-115; ALBERTo NAVARRo, El "Quijote» español, pp. 255-321; PAOLO CHERCHI, «Il Don Quijote nel Seicento Spagnolo», en Capitoli di critica cervantina (1605-1789), Roma, Bulzoni, 1977, pp. 51-70; MANUEL GARCía
} 
Cayóme en gracia la simplicidad de Pedro, que es notable; pero, ¿qué mucho, si soy otro don Quijote, que él sea Sancho Panza? ${ }^{89}$

Especialmente reveladora respecto al personaje de Sancho, y cómo fue visto por los contemporáneos de Cervantes, es la opinión del barbero respecto al hidalgo, en el Quijote de Guillén de Castro:

$$
\begin{aligned}
& \text { Desvanecióse de modo, } \\
& \text { creyendo que eran verdad } \\
& \text { tan negras caballerías, } \\
& \text { que de juïcio incapaz, } \\
& \text { y tomando de su agüelo } \\
& \text { aquel peto y espaldar } \\
& \text { y aplicándole celada } \\
& \text { que tan conforme le está, } \\
& \text { a este villano, tan tosco } \\
& \text { como simple, hizo ensillar } \\
& \text { un rocín, cuyo pellejo } \\
& \text { llenan sus huesos no más }{ }^{90} \text {. }
\end{aligned}
$$

En El mancebón de Los Palacios, de Vélez de Guevara, habla el criadillo del protagonista, y comenta, acerca de las necias ilusiones que les mueven:

Deste Mancebón al trote

Sigo la loca esperanza,

Para ser el Sancho Panza

Deste nuevo Don Quijote ${ }^{91}$.

Y en la continuación apócrifa de Alonso Fernández de Avellaneda, que una vez más nos resultará de especial utilidad para descubrir el significado que el personaje, y la obra en general, tuvieron para un lector medio y típico del siglo XVII, Sancho Panza aparece definido como un "villano, sandio y soez, harto de ajos

MARTín, Cervantes y la comedia española en el siglo XVII, Salamanca, Ediciones de la Universidad de Salamanca, 1980; AsCENSIÓN RIVAS HERNÁNDEZ, Lecturas del Quijote (siglos XVII-XIX), Salamanca, Colegio de España, 1998, con algunas referencias al personaje de Sancho (pp. 62-73); y especialmente R. M. FLORES, Sancho Panza Trough Three Hundred Seventy-Five Years of Continuations, Imitations and Criticism, 1605-1980, Newark, Delaware, Juan de la Cuesta, 1982, pp. 1-23.

${ }^{89}$ Discurso de la viuda de veinticuatro maridos, en Curiosidades bibliográficas, edic. cit., p. 521

90 GuIllén DE CASTRo, Don Quijote de la Mancha, jornada I, escena 20, edic. cit., pp. 82-83.

91 Juan Vélez [DE Guevara], Mancebón de los Palacios, en Dramáticos posteriores a Lope de Vega, edic. de Ramón Mesonero Romanos, Madrid, Atlas, 1951 2 vols. (BAE, 47 y 49), vol. I, p. 593. 
desde la cuna» ${ }^{92}$, un «hombre simplicísimo» ${ }^{93}$, «un labrador harto simple que traía [don Quijote] consigo y él llamaba su escudero ${ }^{94}$, o «un pobre labrador de su mismo lugar [...] muy gracioso y grandísimo comedor ${ }^{95}$. Los comediantes con los que ambos personajes coinciden en una venta, «estaban tan maravillados, que no sabían qué responder a los disparates de uno y simplicidades del otro» ${ }^{96}$; y cuando en el camino se topan con un soldado que regresaba de Flandes:

Volvió el soldado a mirar a Sancho, y como le vio con las barbas espesas, cara de bobo y rellenado en su jumento, pensando que era un labrador zafio de las aldeas vecinas, y no criado de don Quijote, le dijo....97.

\section{ENGAÑOS, PULLAS, VEJÁMENES}

Pero la simpleza proverbial de los villanos, recogida en numerosos cuentecillos, aprovechada por Cervantes y glosada por sus imitadores, además de ser un pasatiempo oral, tuvo su vertiente práctica en la actitud de burla y menosprecio que la población urbana adopta hacia los pobres labriegos que visitan la ciudad, donde con frecuencia son objeto de bromas harto pesadas, algunas de las cuales también se hallan documentadas por escrito. Fray Benito de Peñalosa y Mondragón, por ejemplo, lamentaba en 1629 el hecho de que «quando un labrador viene a la ciudad, y más quando viene a algún pleyto, ¿quién podrá ponderar las desventuras que padece, y los engaños que todos le hazen, burlando de su vestido y lenguage?»" ${ }^{98}$ y añade:

...y estas comedias y entremeses de agora los pintan y remedan haciéndoles aún más incapaces, contrahaciendo sus toscas acciones por más risas del pueblo"

Covarrubias nos explica en su Tesoro que la pulla:

92 Alonso Fernández de Avellaneda, El ingenioso hidalgo don Quijote de la Mancha, edic. cit., parte $5^{\text {a }}$, cap. 10, p. 184.

${ }_{93}$ Ibíd., parte $6^{\text {a }}$, cap. 14 , p. 210.

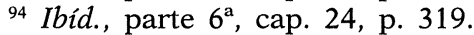

${ }_{95}$ Ibid., parte $7^{\text {a }}$, cap. 29, pp. 382-383.

96 Ibid., parte $7^{\text {a }}$, cap. 26, p. 347 .

${ }^{97}$ Ibíd., parte $6^{\text {a }}$, cap. 14 , p. 200.

98 Fray Benito de Peñalosa, Libro de las cinco excelencias del español, fol. 169.

${ }^{99}$ Ibíd. 
Es un dicho gracioso, aunque algo obsceno, de que comúnmente usan los caminantes quando topan a los villanos que están labrando los campos, especialmente en tiempo de siega o vendimias ${ }^{100}$.

El mismo autor recoge dos términos para designar al patán que visita embobado la ciudad, entre la probable hilaridad de los circunstantes. La primera de ellas es páparo: «El aldeano simple, que viniendo a la ciudad está maravillado y abobado de lo que vee en ella» ${ }^{101}$; y un significado similar tiene pausán: "Corruptamente bausán, el hombre tardo y abobado, como es el villano, quando viene a la ciudad y vee las cosas que no se usan en su aldea»102. Lope de Deza también lamenta en 1618, en su defensa del estado de los labradores:

...la modestia de su vestido, la tez menospreciadora del frío y del sol, las manos duras, a quien teme el hierro y el azero, el sustento agreste, sazonado y diferenciado solamente con su buena gana, la senzillez del lenguage causan risa y mofa a los que, perdido el verdadero conocimiento de la virtud, siguen con sus delicadezas la hypocresía del vicio ${ }^{103}$.

Y el mismo autor explica cómo algunos hijos de aldeanos han salido de su pueblo para seguir sus estudios, y:

...siendo sus padres labradores ellos se crían allí afeminadamente, riéndose ellos después de las comidas y trages de sus casas, pareciéndoles a ellos que han medrado en salir de aquella virtuosa rusticidad que da de comer a todos ${ }^{104}$.

Algunas de las bromas con que las gentes de la ciudad se burlan de los villanos estaban casi institucionalizadas, como las que sufrían los aldeanos que iban el día del Corpus a ver la Tarasca de Toledo, que recoge Covarrubias ${ }^{105}$, o el repelón que los labradores reciben de manos de los estudiantes salmantinos, recordado en uno de sus autos por Juan del Encina ${ }^{106}$; y los cuentos, por su

\footnotetext{
100 SEBASTIÁN DE Covarrubias, Tesoro de la Lengua Castellana, edic. cit., p. 887.

101 Ibíd., p. 851.

102 Ibíd., p. 857.

${ }^{103}$ LOPE DE DEZA, Govierno político de la agricultura, Madrid, 1618, fol. 8.

104 Ibid., fol. 26.

105 "Los labradores, quando van a las ciudades, el día del Señor, están abovados de ver la tarasca, y si se descuydan suelen los que la llevan alargar el pescueço y quitarles las caperuças de la cabeça, y de allí quedó un proverbio de los que no se hartan de alguna cosa que no es más echarla en ellos que echar caperuças a la tarasca» (SEBASTIÁN DE CovarRubias, Tesoro de la Lengua Castellana, edic. cit., p. 954).

106 JUAN DEL EnCINA, «Aucto del repelón», en Teatro completo, edic. de Miguel Ángel Pérez Priego, Madrid, Cátedra, 1998, pp. 221-235.
} 
parte, incluyen ejemplos representativos de tales bromas y enredos. Luis Galindo, por ejemplo, narra esta anécdota referente a un aldeano burlado por un grupo de estudiantes socarrones:

Sabido es el cuentecillo de otro labrador que estando en un mercado vendiendo un lechoncillo, se juntaron cuatro estudiantes, y llegó cada uno separadamente a ponérsele en precio, diciéndole que cuánto quería por aquel ganso. Rióse del primero, y porfió con el segundo. Mas cuando oyó que el tercero y cuarto le decían cada uno que era ganso el que vendía, metióse debajo del capote y llegóse a otros compañeros, casi persuadido y ya dudoso, y preguntóles:

-Amigos, ¿éste es ganso o lechoncillo? ${ }^{107}$.

Otro cuento, recogido por el doctor Carlos García en La desordenada codicia de bienes ajenos, explica cómo un par de pícaros se acercan en el mercado a un labrador que vende gallinas y capones, y le compran todo lo que tiene. Uno de los burladores desaparece con la mercancía, y el otro le dice al vendedor que le acompañe, que luego le pagará. Recorren algunas calles, llegan a un convento en cuya capilla se encuentran unos frailes confesando; el ladrón dice al labriego que las provisiones que han comprado son para el convento, que aguarde un poco a que uno de los frailes acabe de confesar, que le pagará, y al fraile le pide en voz baja que por favor confiese a aquel villano que aguarda de pie, que vive lejos y tiene prisa para volver a su aldea; tras lo cual el pícaro desaparece, dejando al fraile en disposición de oír los pecados del aldeano, y a éste pensando que va a cobrar el precio de sus gallinas ${ }^{108}$. $\mathrm{Y}$ en El coloquio de los perros, Cervantes recoge el cuento del asno vendido dos veces, protagonizado en este caso por un astuto gitano, el cual tomó un burro, le puso una cola postiza que parecía real, y se lo vendió por buen precio a un labrador. Luego consiguió robar el asno que acababa de vender, y le dijo al aldeano que si quería comprar un burro hermano del anterior por un precio aun inferior. Aceptó el labriego, y el gitano despojó al asno de su cola falsa, le cambió los aparejos, y vendió el burro al mismo comprador por segunda vez ${ }^{109}$.

107 LUIS GALINDO, Sentencias filosóficas y verdades morales, que otros llaman proverbios o adagios castellanos, manuscrito de la Biblioteca Nacional (mss. 9.7729.781), 1659-1668, 10 vols., vol. II, fol. 275; cit. por MAXIME CHEVALIER, Cuentos folklóricos, p. 297.

${ }^{108}$ CARlos García, La desordenada codicia de bienes ajenos, cap. VII, en La novela picaresca española, edic. cit., vol. II, pp. 118-120; y MAXIME CHEVALIER, Cuentos folklóricos, p. 277.

${ }^{109}$ Miguel DE CERVANTES, Novelas ejemplares, en Obras completas, edic. cit. vol. II, p. 288 . 
Si volvemos al Quijote, advertiremos que Sancho es objeto de un conjunto de burlas que, en su fondo y su intención, recuerdan a las que sufrían tanto los protagonistas de los cuentos como los labradores reales cuando visitaban la ciudad, y que los lectores de la época debieron de tener presentes al leer el libro: En la venta lo mantean unos pícaros, o intentan hacerle creer, como a su amo, que la bacía es un yelmo - una broma similar a la del ganso y el lechoncillo citada-; siendo huésped de los Duques le hacen viajar en Clavileño; Merlín le recomienda una crecida ración de azotes para desencantar a Dulcinea; es objeto de pesadas burlas durante el gobierno de la ínsula Barataria, desde el forzoso ayuno que le impone Pedro Recio al pisoteo con que termina el reinado; y finalmente ha de sufrir una tanda de alfilerazos y pellizcos para que Altisidora resucite.

\section{UN VILLANO BELLACO, SOCARRÓN Y MALICIOSO}

Pero el campesino de los cuentos, y probablemente el campesino real, no era tan manso y sufrido como se deduce de las anécdotas que acabamos de citar, y la necesidad de defenderse, el simple espíritu de supervivencia, junto a las penurias de toda clase que debía soportar, le llevaron a arreglárselas para contrarrestar, e incluso vencer, a sus burladores, y para sobrevivir entre las penalidades y las burlas desplegando una extraordinaria inventiva, de donde le vino fama de astuto e ingenioso, y también de malicioso y bellaco.

El labrador, en efecto, adiestrado por la necesidad, que según dicen es maestra inigualable ${ }^{110}, \mathrm{y}$ al sentirse víctima constante de

110 En aquella época llegó a ser un tópico la antigua máxima según la cual la necesidad, y nadie la sufría más que el campesino, era capaz de avivar los ingenios y aguzar la astucia. Ya en el acto IX de La Celestina se lee: «La necessitad y pobreza, la hambre, que no ay mejor maestra en el mundo, no ay mejor despertadora y abivadora de ingenios. ¿Quién mostró a las picaças y papagayos ymitar nuestra propia habla con sus harpadas lenguas, nuestro órgano y boz, sino ésta?» (FERNANDo DE RoJAS, La Celestina, edic. de Dorothy S. Severin, Madrid, Cátedra, $4^{a}$ edic., 1990, p. 224). Don Juan de Arguijo explicaba en uno de sus cuentos que, en lugar de tres, los pobres tienen "cuatro potencias del alma, una más que los ricos, que es la necesidad, que es ingeniosa" (Cuentos recogidos por Juan de Arguijo, edic. cit., p. 231, núm. 587). En el Guzmán de Alfarache, la necesidad ues maestra de todas las cosas, invencionera sutil, por quien hablan los tordos, picazas, grajos y papagayos" (MATEO AlEMÁN, Guzmán de Alfarache, $1^{\mathrm{a}}$ parte, lib. II, cap. 1, en La novela picaresca española, edic. cit., vol. I, p. 366). Ella, según Covarrubias, "despierta los ingenios y halla camino a lo que parecía impossible» (SEBASTIÁN DE CovARRUBIAS, Emblemas morales, Madrid, 1610, y edic. facsímil a cargo de Carmen Bravo-Villasante, Madrid, Fundación Universitaria Española, 
vejaciones y burlas, se torna por fuerza desconfiado, socarrón y malicioso, capaz de desplegar ante nuestros ojos la más increíble astucia: llega a ser un tonto-listo, un auténtico maestro en la difícil ciencia de la gramática parda, demostrando a menudo el suficiente caletre para reírse de sus burladores, lo cual también pasó a formar parte de la tradición oral, con cuentos que podrían englobarse bajo el rótulo común de «el burlador burlado», y en que el villano suele quedar vencedor. Joan de Timoneda, por ejemplo, recoge este cuentecillo en su Sobremesa y alivio de caminantes:

Una moza aldeana llevaba delante de sí una burra, que, por ir a su mismo lugar, do tenía su pollino, caminaba más que la moza. Encontrándose con un cortesano, díjole:

- Hermana, ¿de dónde bueno sois?

Respondió ella:

-Señor, de Getafe.

-Decidme, ¿conocéis en ese lugar la hija de Lope Hernández?

Dijo ella:

-Muy bien la conozco.

-Pues hacedme tan señalado placer, que, de mi parte, le llevéis un beso.

Respondió el aldeana:

-Señor, délo a mi burra, porque llegará antes que yo ${ }^{111}$.

El propio Timoneda recoge otro cuento parecido:

Un villano iba caballero en un rocín muy largo y flaco. En el camino, encontrándose con un caballero, díjole, por burlarse con él:

1978, p. 159); y según Lope de Deza, «No se puede creer bien el ingenio, y industria que cría la necessidad, que como dixo el otro, enseña a hablar a los papagayos y hurracas» (LOPE DE DEZA, Govierno político de la agricultura, fol. 73). "La necesidad hace a la vieja trotar y al goloso saltar» y "La necesidad hace maestros», según GONZALO CORREAS (Vocabulario de refranes, edic. cit., p. 185); y Cervantes enuncia la misma idea en varias ocasiones: "De todo hay en el mundo, y esto de la hambre tal vez hace arrojar los ingenios a cosas que no están en el mapa», leemos en La Gitanilla (MIGUEL DE CERVANTES, Novelas ejemplares, en Obras completas, edic. cit., vol. II, p. 15); y en el Persiles: «la necesidad, según se dice, es maestra de sutilizar el ingenio" (MIGUEL DE CERvanTES, Los trabajos de Persiles y Sigismunda, lib. I, cap. 9, ibid., vol. II, p. 890).

111 JOAN DE TIMONEDA y JOAN ARAGONÉS, Buen aviso y portacuentos. Sobremesa $y$ alivio de caminantes. Cuentos, edic. de Pilar Cuartero y Maxime Chevalier, Madrid, Clásicos Castellanos nueva serie, 1990, pp. 240-241, núm. 63. También Correas recoge el dicho popular «Dalde a mi burra, que llegará primero», y lo glosa con el mismo cuento: "Dicen que un galán cortesano, viendo una labradora bonita que se volvía de la villa a su aldea, la dijo que le llevase un beso a cierta persona de allá; ella respondió lo dicho, porque llevaba delante la burra" (GoNZALO CORREAS, Vocabulario de refranes, edic. cit., p. 309). Puede verse en MAXIME CHEVAlier, Cuentecillos, pp. 169-170. 
- Hermano, ¿a qué precio vendéis la vara del rocín? Respondió de presto el villano, alzando la cola de su rocín: -Señor, entrad en la botica, y decíroslo han ${ }^{112}$.

El mismo autor incluye en su colección este otro cuento, protagonizado por un pastoricllo avispado y respondón:

Estando en corrillo ciertos hidalgotes, vieron venir un pastor a caballo con su borriquilla, y tomándolo en medio, por burlarse de él, dijéronle: - ¿Qué es lo que guardáis, hermano?

El pastor, siendo avisado, respondióles:

-Cabrones guardo, señores.

Dijéronle:

- ¿Y sabéis silbar?

Diciendo que sí, importunáronle para que silbase, por ver qué silbo tenía. Ya que hubo silbado, dijo el uno dellos:

- ¿Qué?, ¿no tenéis más recio silbo que éste?

Respondió:

-Sí señores; pero éste abasta para los cabrones que me oyen ${ }^{113}$

Otro divertido ejemplo de campesino listo, aunque tonto en apariencia, nos lo ofrece Timoneda en la colección citada ${ }^{14}$ : Un labriego, creyendo que los monarcas debían de ser figuras sobrehumanas, pidió a su amo el sueldo que le debía y se fue a la corte para ver al rey; pero todo salió al revés de lo que esperaba: Se gastó el dinero que llevaba, le vino un dolor de muelas, y tras ver al rey se quedó decepcionado al comprobar que era un hombre como los demás: «¡Oh, pésete a la puta que no me parió —exclama-, que por ver un hombre he gastado lo que tenía, que no me queda sino medio real en todo mi poder!». Así que se encontró en mitad de la corte hambriento, con sólo medio real, y con la duda de en qué gastar el dinero: en comer unos pasteles tras los que se le están yendo los ojos, o en sacar la muela enferma. Pero la solución llega pronto gracias a unos estudiantes que quieren burlarse de él, y con los que apuesta que se comerá nada menos que quinientos pasteles, y si no lo logra, dejará que el barbero le arranque una muela. Naturalmente pierde la apuesta, y los estudiantes, que creen estar divirtiéndose a su costa, le pagan el convite y el trabajo del barbero. Y en su Buen aviso y portacuentos, Timoneda nos ofrece esta otra anécdota:

Habíase caído un asno cargado de leña a un villano en corte, y, como le estuviese dando de palos, vino a pasar por allí el contador del rey, por do le dijo:

112 Ibíd., p. 241, núm. 64.

113 Ibíd., p. 212, núm. 15; y MaXime Chevalier, Cuentos folklóricos, p. 333.

114 Ibíd., pp. 216-218, núm. 22. 
- Hermano, a paso eso.

Dejando de darle al asno, paróse, y quitando el bonete, como que razonaba con él, dijo:

-Así que, don asno, parientes tenéis en corte. De aquí adelante trataros hemos con más cortesía ${ }^{115}$.

Sancho presenta la doble faz del campesino típico que venimos comentando, y como han señalado varios $\operatorname{críticos}^{116}$, es un personaje claramente emparentado con los campesinos del folklore, bobo y listo, ingenuo y malicioso al mismo tiempo, simplón y a la vez bellaco, capaz de la mayor estupidez y la mayor agudeza, detalles que también resultarían evidentes para los lectores de la época:

Ya te tengo dicho antes de agora muchas veces, Sancho - dijo don Quijote-, que eres muy grande hablador y que, aunque de ingenio boto, muchas veces despuntas de agudo (I, 25, 284).

Durante la segunda estancia en el palacio ducal:

...dijo Sancho tantos donaires y tantas malicias, que dejaron de nuevo admirados a los duques, así con su simplicidad como con su agudeza (II, 70, 1197). dero:

Y hablando con los Duques, don Quijote explica que su escu-

\begin{abstract}
...tiene a veces unas simplicidades tan agudas, que el pensar si es simple o agudo causa no pequeño contento; tiene malicias que le condenan por bellaco y descuidos que le confirman por bobo; duda de todo y créelo todo; cuando pienso que se va a despeñar de tonto, sale con unas discreciones que le levantan al cielo (II, 32, 900).
\end{abstract}

Cervantes, en efecto, al menos en apariencia, parece aceptar el tópico de la malicia y la socarronería del villano, que aparecen mezcladas, como hemos visto, con su tradicional simplicidad, y lo aprovecha para acentuar la comicidad de Sancho Panza, convertido con frecuencia en uno de aquellos labriegos de los cuentos, capaces de salir airosos de situaciones difíciles, de volver con creces las burlas de que son objeto, de proferir comentarios maliciosos, o de actuar con estudiada doblez: Recordemos, por ejemplo, cómo Sancho se burla de don Quijote durante la aventura de los batanes, contándole el cuento de la pastora Torralba, que no tiene fin, o remeda en tono jocoso las palabras que su amo profirió

115 Ibid., p. 172, núm. 56

116 Véase antes, notas 71-73. 
el día anterior - «Has de saber, joh Sancho amigo!, que yo nací, por querer del cielo, en esta nuestra edad de hierro, para resucitar en ella la dorada, o de oro»-, despertando su cólera con ello:

Viendo, pues, don Quijote que Sancho hacía burla dél, se corrió y enojó en tanta manera, que alzó el lanzón y le asentó dos palos, tales, que si como los recibió en las espaldas los recibiera en la cabeza, quedara libre de pagarle el salario, si no fuera a sus herederos (I, 20219 ).

Al descubrir que Dorotea, a la que él cree princesa Micomicona, besa a don Fernando, los comentarios que profiere Sancho no tienen desperdicio por su perversa malicia:

...que yo tengo por cierto y por averiguado que esta señora que se dice ser reina del gran reino Micomicón no lo es más que mi madre, porque a ser lo que ella dice no se anduviera hocicando con alguno de los que están en la rueda, a vuelta de cabeza y a cada traspuesta [...].

Esto digo, señor, porque si al cabo de haber andado caminos y carreras, y pasado malas noches y peores días, ha de venir a coger el fruto de nuestros trabajos el que se está holgando en esta venta, no hay para qué darme priesa a que ensille a Rocinante, albarde el jumento y aderece al palafrén, pues será mejor que nos estemos quedos, y cada puta hile, y comamos (I, 46, 533-34).

Cuando don Quijote envía a Sancho Panza al Toboso con una carta para Dulcinea, el mensajero no lleva la misiva, pero explica a don Quijote con todo detalle los pormenores de su embajada amorosa (I, 31). Cuando se inicia la segunda parte, el labriego aprovecha la locura de su amo para hacerle creer que tres labradoras que salen del Toboso son Dulcinea y sus damas (II, 10). Al entrar en el palacio de los Duques, Sancho pide a la linajuda y compuesta doña Rodríguez que lleve su asno hasta la cuadra, tras lo cual la llama vieja sin miramientos:

- Hermano, si sois juglar — replicó la dueña-, guardad vuestras gracias para donde lo parezcan y se os paguen, que de mí no podréis llevar sino una higa.

-iAun bien - respondió Sancho- que será bien madura, pues no perderá vuesa merced la quínola de sus años por punto menos!

- Hijo de puta - dijo la dueña, toda ya encendida en cólera-, si soy vieja o no, a Dios daré la cuenta que no a vos, bellaco harto de ajos (II, $31,881-82$ ).

Y cuando el Duque y don Quijote porfían sobre quién debe ocupar la cabecera de la mesa, Sancho desembaula su malicia y cuenta un suceso, ocurrido en su lugar, del que se deduce que el superior, se siente donde se siente, siempre será cabeza del inferior, con lo cual: 
Púsose don Quijote de mil colores, que sobre lo moreno le jaspeaban y se le parecían; los señores disimularon la risa, porque don Quijote no acabase de correrse, habiendo entendido la malicia de Sancho (II, 31, 887).

En resumen, Sancho Panza, con sus «malicias que le condenan por bellaco, y descuidos que le confirman por bobo» (II, 32, 900 ), se nos presenta, igual que los aldeanos que protagonizan los cuentos que hemos citado, como un "socarrón de lengua viperina» (I, 30, 352), que «mejor desata la lengua para decir malicias que ata y cincha una silla para que esté firme» (II, 30, 878), "un costal lleno de refranes y de malicias» (II, 43, 978), "un tonto, aforrado de lo mismo, con no sé qué ribetes de malicioso y de bellaco» (II, 58, 1104), y un «bellaco villano, malmirado, descompuesto, ignorante, infacundo, deslenguado, atrevido, murmurador y maldiciente» (I, 46, 534). Y él mismo lo reconoce diciendo:

\begin{abstract}
...bien es verdad que soy algo malicioso y que tengo mis ciertos asomos de bellaco, pero todo lo cubre y tapa la gran capa de la simpleza mía, siempre natural y nunca artificiosa (II, 8, 689).
\end{abstract}

\title{
7. COMO VILLANO RUIN, NACIDO Y CRIADO ENTRE ELLOS
}

La tradición folklórica relativa a la bobería y malicia del labriego que venimos comentando, deriva, lógicamente, de una corriente de opinión muy extendida según la cual el villano es por naturaleza, y por el propio ambiente en que se desarrolla su existencia, un ser ignorante, malicioso y tosco. Ya Fray Antonio de Guevara censuraba al vanidoso cortesano que mira con menosprecio a la gente rústica, y piensa que:

...todos los que biven fuera de la corte son nescios y él sabio, son rudos y él agudo, son apocados y él honrado, son torpes y él polido, son cortos y él bien hablado, son locos y él cuerdo ${ }^{117}$.

$\mathrm{Y}$ añade:

Mucho me cae a mí en gracia que si uno ha estado en la corte y agora bive en la villa o en el aldea, llama a todos patacos, moñacos toscos, groseros y mal criados, motejándolos de muy desaliñados en el vestir y de muy grosseros en el hablar ${ }^{118}$.

117 FRAY ANTONIO DE Guevara, Menosprecio de corte y alabanza de aldea, edición de Matías Martínez Burgos, Madrid, Espasa-Calpe, Col. Clásicos Castellanos, $6^{\mathrm{a}}$ edic., 1975, p. 142.

${ }^{118}$ Ibíd., p. 143. 


\section{Alonso Remón escribe:}

...en los labradores y aldeanos, no sólo la ignorancia, pero la rustiquez de su trato, y viuienda campestre, se les suele connaturalizar mucho de la malicia ${ }^{119}$.

Uno de los interlocutores de los Diálogos familiares de Fray Juan de Pineda, recogiendo la opinión común acerca de los labriegos, afirma que:

...la ignorancia favorece mucho a la necedad, y la necedad a la malicia, [...] y los labradores son tan ignorantes como rústicos, y la rusticidad les es inseparable, pues andan siempre al campo, que se llama rus en latín; luego también la malicia les es como connatural, y la malicia lleva al infierno, y ansí probamos que dicen mal los que alaban el estado de los labradores, como a más seguro para se salvar en él ${ }^{120}$.

En el Guzmán de Alfarache se lee:

Líbreos Dios de villanos, que son tiesos como encinas y de su misma calidad. El fruto dan a palos, y antes dejarán arrancarse de cuajo por la raíz, quedando destruidos y sus haciendas asoladas, que dejarse doblar un poco. Y si dan en perseguir, serán perjuros mil veces en lo que no les importa una paja, sino sólo hacer mal. Y es lo malo y peor que piensan los desdichados que así se salvan y por maravilla se confiesan de aquella ponzoña ${ }^{121}$.

Según Baltasar Gracián, la malicia quiso hacerse cortesana, mas al ver que la corte no era lugar para ella:

Dio por otro extremo, que fue meterse a villana, y salióla tan bien, que al punto se vio adorada de toda la verídica necedad. Allí triunfa porque allí habla, discurre, aunque a lo zonzo, y pega valientes mazadas de necedades, que ella llama verdades. Llegó esto a tanto exceso de crédito y afecto que, porque no se les hurtasen o matasen, trazaron los villanos meterla dentro de sus entrañas, donde la hallan siempre los que menos querrían ${ }^{122}$.

Incluso un defensor del estado de los labradores como el ya citado Lope de Deza, escribe en su Gobierno político de la agricultura:

119 ALONSO REMÓN, Entretenimientos y juegos honestos y recreaciones christianas, Madrid, 1623, fol. 74 .

120 Fray JUAN DE PINEDA, Diálogos familiares de agricultura cristiana, edic. del P. Juan Meseguer Fernández, Madrid, Atlas, 1963-1964, 5 vols. (BAE, 161-163 y 169-170), vol. III, p. 256.

121 Mateo Alemán, Guzmán de Alfarache, $2^{\mathrm{a}}$ parte, lib. I, cap. 8, en La novela picaresca española, edic. cit., vol. I, pp. 361-362.

${ }^{122}$ Baltasar Gracián, El Criticón, edic. de Evaristo Correa Calderón, Madrid, Espasa-Calpe, Col. Clásicos Castellanos, 1971, 3 vols., vol. I, pp. 148-49. 
...los labradores se han fabricado su mismo menosprecio, porque [...] ha sucedido a su inocencia, malicia, a su senzillez engaño, a su liberalidad escaseza, a su misericordia codicia ${ }^{123}$.

En la obra de Cervantes no faltan opiniones similares: «el hacer bien a villanos es echar agua en la mar» (I, 23, 248), leemos en el Quijote. El propio caballero andante reprocha a su escudero el hecho de que se comporte "como villano ruin que sois, criado y nacido entre ellos» (I, 20, 220). Al contar el pastor Eugenio su historia, y la llegada a la aldea del soldado Vicente de la Roca, el personaje comenta:

La gente labradora, que de suyo es maliciosa y dándole el ocio lugar es la misma malicia, lo notó, y contó punto por punto sus galas y preseas, y halló que los vestidos eran tres, de diferentes colores, con sus ligas y medias (I, 51, 578).

$\mathrm{Y}$ en el refranero abundan los juicios despectivos acerca de los villanos, similares a los ya citados: "Al villano, no le hagas bien, que es perdido, ni mal, que es pecado», "Al villano, dalde el pie y tomaros ha la mano», "El sarmiento y el villano es porfiado», "No hagas bien a villano, ni bebas agua de charco», "Quien hace servicio al villano, escúpese en la mano», "Mátenme traidoras manos y no me den vida villanos», "Mozo mísero, y abad ballestero, y villano cortés, lleve el diablo a todos tres» ${ }^{124}$.

Naturalmente, la opinión negativa acerca de los labriegos tiene un importante componente de tipo ideológico y social, claramente perceptible en los testimonios que acabamos de citar, y que no habrá pasado inadvertido al lector; y otro tanto podríamos decir acerca de la veta cómica del rústico, presente en cuentecillos y chistes, y que los dramaturgos y otros creadores explotaron reiteradamente. La comicidad, en efecto, es un acontecimiento colectivo, impregnado de ideología, y que rara vez puede ser calificado de espontáneo e inocente. El sujeto de la risa, como señaló Bergson, es un grupo de individuos ${ }^{125}$, y no es raro que su destinatario sea algún sector social, encarnado a veces en ciertos personajes prototípicos, al que se pretende zaherir, menospreciar o excluir (la risa de Quevedo, entre otros, nos proporcionaría multitud de ejemplos). Y si volvemos la vista a nuestro Siglo de Oro y a la figura del campesino ridículo, bastará que recordemos, para

\footnotetext{
${ }^{123}$ LOPE DE DEZA, Govierno político de la agricultura, fol. 8.

124 Gonzalo Correas, Vocabulario de refranes, edic. cit., pp. 45, 90, 263, 419, 546,560 .

${ }^{125}$ Henri Bergson, La risa, México, Espasa-Calpe Mexicana, Col. Austral, 1994, pp. 17-18.
} 
confirmar lo dicho, que en aquellos años, entre los sectores urbanos de la sociedad, y especialmente para la minoría aristocrática, prevalece la idea de que los labriegos, por su nacimiento y su crianza, son incapaces de adquirir modales, educación, inteligencia o saber, o de comportarse como personas discretas, y la maldad parece ser consustancial en ellos, de manera que, a pesar de los esfuerzos de algunos tratadistas y dramaturgos para dignificar la agricultura y la consideración social del labrador, la actitud despectiva hacia los rústicos, convertidos en hazmerreír y en objeto de pesadas burlas por parte de quienes se sienten superiores, será activa durante largo tiempo. De esta forma, como señaló Noël Salomon ${ }^{126}$, el tópico de la bobería y la malicia del villano vendrá a ser el reflejo de una mentalidad aristocrática que quiere ver en el labrador a un personaje inferior, desprovisto de aquellas cualidades que el noble hereda en la sangre y afianza con su rango, en una época en que, según el sentir común generalmente aceptado, «de los nobles siempre se presume cualquier cosa buena y virtuosa", como explicaba Castillo de Bovadilla ${ }^{127}$, mientras que de los que no nacen de alta cuna sólo pueden esperarse actos reprobables, teniendo en cuenta que «la sangre ruin engendra pensamientos ruines», según Juan de Zabaleta ${ }^{128}$.

\section{SANCHO BUENO, SINCERO Y DISCRETO, O CÓMO FUERON BURLA- DOS LOS BURLADORES}

Aunque de los datos que hemos expuesto hasta ahora parece deducirse que Cervantes, al diseñar el personaje de Sancho, aceptó el tópico de la bobería y la malicia del villano, una lectura más atenta de su obra nos llevaría a conclusiones opuestas, y a comprobar cómo el autor ha llevado a cabo en el Quijote una verdadera transformación subversiva de la figura estereotipada del labriego, algo que también debieron de advertir, suponemos, los lectores más atentos de su época, aunque no podemos afirmarlo con igual certeza en el caso de Alonso Fernández de Avellaneda, el cual, o no percibió la novedosa reversibilidad e inteligencia del labrador cervantino, y en su lugar diseñó un personaje plano, desprovisto de matices, o, si lo hizo, procuró desmontar lo que de renovador presentaba el modelo ideado por Cervantes, y asignó a

${ }^{126}$ NoËl SALOMON, Lo villano en el teatro del Siglo de Oro, pp. 56 y ss.

127 Jerónimo CASTILlo DE Bovadilla, Política para corregidores y señores de vassallos, Madrid, 1597, 2 vols., vol. I, p. 93.

128 JuAn De Zabaleta, El día de fiesta por la tarde, edic. de José María Díez Borque, Madrid, CUPSA, 1977, p. 89. 
su falso Sancho Panza los defectos y cualidades ridículas que, por su condición y origen, y situándonos en la órbita de la ideología aristocrática, debe poseer todo labriego: un villano "sandio y soez", «harto de ajos desde la cuna» ${ }^{129}$ y un "grandísimo malicioso» ${ }^{130}$, según vimos.

Para Cervantes, en cambio, y en contra de la opinión mayoritaria en la época, "la sangre se hereda y la virtud se aquista, y la virtud vale por sí sola lo que la sangre no vale» (II, 42, 970-71). De esa forma, un aldeano aparentemente malicioso puede ser un dechado de bondad, y el labriego tonto, un gobernador discreto y justo, como veremos a continuación, porque «nadie nace enseñado, y de los hombres se hacen los obispos, que no de las piedras» (II, 33, 908).

Recordemos en primer lugar que, frente a aquella malicia que repetidamente se achacaba a los labriegos, Sancho Panza se nos muestra en múltiples ocasiones como un personaje bondadoso, capaz de seguir a don Quijote, no sólo para buscar el sustento de los suyos, sino movido también por su bondad natural y por la fidelidad y el agradecimiento que le unen al hidalgo ${ }^{131}$, según explica él mismo en uno de los elogios de la amistad más conmovedores de nuestra literatura:

Pero esta fue mi suerte y esta mi malandanza: no puedo más, seguirle tengo; somos de un mismo lugar, he comido su pan, quiérole bien, es agradecido, diome sus pollinos, y, sobre todo, yo soy fiel, y, así, es imposible que nos pueda apartar otro suceso que el de la pala y el azadón (II, 33, 906).

Tras conocer a Sancho Panza, el Caballero del Verde Gabán exclama: "vos sí, hermano, que debéis de ser bueno, como vuestra simplicidad lo muestra» (II, 16, 755). Para don Quijote, su escudero «es el mejor hombre del mundo» (I, 50, 572): «Sancho bueno, Sancho discreto, Sancho cristiano y Sancho sincero» (II, 11, 717-18); y al hacer su testamento explica:

...y si, como estando yo loco fui parte para darle el gobierno de la ínsula, pudiera agora, estando cuerdo, darle el de un reino, se le diera, porque la sencillez de su condición y fidelidad de su trato lo merece (II, $74,1219)$

\footnotetext{
${ }^{129}$ Alonso Fernández de Avellaneda, El ingenioso hidalgo don Quijote de la Mancha, edic. cit., parte $5^{\text {a }}$, cap. 10, p. 184 .

${ }_{130}$ Ibid., parte $7^{\mathrm{a}}$, cap. 27, p. 367.

131 Véase LEIF SLETSJÖE, Sancho Panza, hombre de bien, Madrid, Ínsula, 1961, especialmente pp. 18-24; y TERESA AVELEYRA DE ARROYO ANDA, "Un hombre llamado Sancho Panza», Nueva Revista de Filología Hispánica, XXII, 1973, pp. 1-16, que presta especial atención al tema de la amistad entre el hidalgo y su escudero.
} 
Pero Cervantes no sólo insiste en la bondad natural que Sancho Panza esconde tras su apariencia de labriego socarrón, sino que, además, de manera repetida, le adjudica cualidades privativas de los nobles, $\mathrm{y}$, por consiguiente, impropias de los villanos, en especial la condición de discreto. Desde el punto de vista de la ideología nobiliaria dominante en esta época, el labriego, además de malicioso y bobo, defectos que parecen consustanciales en él, también puede ser en ocasiones astuto y aun agudo, como aquellos protagonistas de los cuentecillos citados anteriormente, o como se dice en varias ocasiones a propósito de Sancho, según vimos. La astucia, según explicaba Covarrubias, es «el ardid con que uno engaña [...]; de allí astuto, el sagaz y cauteloso ${ }^{132}$, un término que encierra, por consiguiente, un sentido peyorativo muy claro; y en cuanto a la agudeza, que el mismo autor define como el «ingenio sutil y penetrante» ${ }^{133}$, y el Diccionario de Autoridades como la "prontitud y facilidad de ingenio ${ }^{134}$, es palabra que en la época puede aparecer rodeada de connotaciones negativas, no sólo por su parentesco con la astucia, la doblez maliciosa y la sátira mordaz ${ }^{135}$, sino también por su relación con la limpieza de sangre: La agudeza es la inteligencia natural, con ribetes de malicia, que poseen los plebeyos, y sobre todo, en grado máximo, los judíos y conversos, de manera que tanto su posesión como su cultivo mediante el estudio podían ser infamantes, y, si no iba acompañada por virtudes de otro tipo, algo impensable entre gentes bien nacidas ${ }^{136}$.

132 Sebastián de Covarrubias, Tesoro de la Lengua Castellana, edic. cit., p. 161. Según el Diccionario de Autoridades, la astucia es el «Ardid y cautela maliciosa para engañar, usando con sagacidad de medios al parecer no proporcionados al fin que se desea" (REAl ACADEMIA EsPañola, Diccionario de Autoridades [1726-1739], edición facsímil, Madrid, Gredos, 1990, 5 tomos en 3 vols., tomo I, p. 452.

133 Ibíd., p. 52.

134 Diccionario de Autoridades, edic. cit., tomo I, p. 128.

${ }^{135} \mathrm{La}$ palabra agudo, según el Diccionario de Autoridades, "Metaphóricamente vale ingenioso, pronto, perspicaz, y sutil», aunque "También por metáhora vale picante, ingenioso y que pica en satýrico: como son los pasquines, y modos de decir o hablar con alusión y equívoco» (ibíd., tomo I, p. 129).

${ }^{136}$ Lo señaló AMÉRICO CASTRO, con estilo polémico y tono provocador, aunque con pruebas difíciles de rebatir, en De la edad conflictiva. Crisis de la cultura española en el siglo XVII, Madrid, Taurus, $3^{\text {a }}$ edic., 1972, pp. 153 y ss.: "Ni judío necio, ni liebre perezosa», reza un refrán recogido por GoNZALO CORREAS (Vocabulario de refranes, edic. cit., p. 232). En la probanza de limpieza del Bachiller Martín Martínez Cantalapiedra, verificada el 15 de junio de 1551 en el Colegio de San Bartolomé de Salamanca, al haber opositado en él el entonces joven Martín Matínez, uno de los testigos, Gregorio de Padinas, declaró que no ponía en duda la limpia cristiandad de la familia paterna del opositor, aunque también dijo que «al Lope Rodríguez, vecino desta villa [Cantalapiedra], ya defunto, oyó decir algunas veces, en especial cuando se enojaba de Sebastián Martínez e sus hermanos, que creía e que no podía ser menos sino que venían de conversos, según 
La discreción ${ }^{137}$, en cambio, aunque también implique la posesión de cualidades como la inteligencia y la agudeza ${ }^{138}$, estriba sobre todo en la prudencia, el control de la voluntad y la capacidad de adaptación ${ }^{139}$ : Una virtud propia del «hombre cuerdo y de buen seso, que sabe ponderar las cosas y dar a cada una su lugar ${ }^{140}$, imprescindible en el trato cortesano ${ }^{141}$, y que posee de forma casi exclusiva la gente de sangre noble ${ }^{142}$, como atestiguan muchos textos de la época en que ambos términos van emparejados ${ }^{143}$, y

eran agudos» (Proceso criminal contra el hebraísta salmantino Martín Martínez de Cantalapiedra, edic. de Miguel de la Pinta Llorente, Madrid, Instituto Arias Montano del CSIC, 1946, p. L). En un informe redactado por Lorenzo Galíndez de Carvajal al comienzo de reinado de Carlos I, en que se dan noticias acerca de la condición y origen de algunos consejeros del Emperador, se dice, entre otras cosas, que «El doctor Beltrán tiene buenas letras y es agudo [...]. Todos tienen que sería buena provisión poner otro en su lugar, porque ni su linaje ni manera de vivir, ni sus costumbres y fidelidad, ni secreto del Consejo son para ser consejero de ningún Señor, cuanto más de tan gran Rey y Emperador» («Informe que Lorenzo Galíndez de Carvajal dio al Emperador Carlos V sobre los que componían el Consejo Real de S. M.», en Documentos Inéditos para la Historia de España, I, 1842, pp. 122-127, y p. 125 para el fragmento citado). El Padre Sigüenza explica las dificultades que fray Hernando de Talavera, siendo arzobispo de Granada, tuvo para predicar a los judíos, "porque como son naturalmente agudos, y tienen tan en los labios la Escritura Santa, argüían muchas vezes contra lo que se les predicaba" (FRAY José DE SigüEnZA, Historia de la Orden de San Jerónimo, Madrid, Nueva Biblioteca de Autores Españoles, vols. VIII y XII, 1907-1909, vol. II, p. 307).

${ }_{137}$ A pesar de su título, y al haber quedado inconcluso (sólo alcanza hasta el reinado de los Reyes Católicos), el libro de BERNARDo Blanco-GonZÁlez (Del cortesano al discreto: Examen de una decadencia, Madrid, Gredos, 1962) apenas ofrece datos sobre el valor de la discreción en la sociedad del siglo XVII. Sí es útil, en cambio, más allá de lo que su título sugiere, el libro de MARGARET S. BATES, "Discreción" in the Works of Cervantes: A Semantic Study, Washington, The Catholic University of America Press, 1945.

138 MARGARET S. BATES, "Discreción» in the Works of Cervantes, pp. 45 y ss.

139 Ibíd., pp. 1 y ss., 12 y ss., y pássim.

140 SEBASTIÁN DE CovarRuBias, Tesoro de la Lengua Castellana, edic. cit., p. 475. Según el Diccionario de Autoridades, la discreción es la "Prudencia, juicio y conocimiento con que se distinguen y reconocen las cosas como son, y sirve para el gobierno de las acciones y modo de proceder, eligiendo las más a propósito" (edic. cit., tomo III, p. 297).

${ }^{141}$ MARGARET S. BATES, "Discreción" in the Works of Cervantes, pp. 66 y ss.

142 Ibíd., pp. 72 y ss.

143 «Era el marqués de los Vélez valeroso y esforzado caballero y muy discreto; mas no se podía determinar cuál era en él mayor extremo, su esfuerzo, valentía y discreción, o la arrogancia y ambición de honra, acompañada de aspereza de condición, a que demasiadamente era inclinado» (LUIS DE MÁRMOL CARVAJAL, Rebelión y castigo de los moriscos del Reino de Granada, lib. VI, cap. 26, en Historiadores de sucesos particulares, edic. de Cayetano Rosell, Madrid, Atlas, 1946 (BAE, $21)$, p. 277. "Porque sabía bien que los dos eran entonces los galanes de más nombre, de ilustre sangre, discretos, gallardos de talle y trato, curiosos en sus vestidos, generales y briosos en todas gracias» (MATEO AlEMÁN, Guzmán de Alfarache, 2. ${ }^{a}$ parte, lib. I, cap. 4, en La novela picaresca española, edic. cit., vol. I, 
como corrobora Baltasar Gracián, el cual define la discreción como la sabia mezcla del «genio y el ingenio», el «majestuoso señorío en el hacer y en el decir», la "cuerda intrepidez, contraria al deslucido encogimiento», "una cierta sabiduría cortesana», junto a "una conversable sabrosa erudición», cualidades que suelen ir acompañadas por «el despejo, la bizarría de acciones, la plausibilidad y ostentación, con otras muchas de este lucimiento", y por supuesto con la Galantería, la cual, hablando directamente al lector, afirma no caber «en todos, porque supongo magnanimidad; y con tener tantos pechos un villano, para la galantería no la tiene. [...] Préciome de muy noble y lo soy, hidalga de condición y de corazón»" ${ }^{144}$.

p. 507). «El soldado, que tenía tanto de discreto y noble cuanto de plática militar, conoció luego el blanco a que tiraba con la pregunta su cortés huésped" (ALONSo FERNÁNDEZ DE AVELlANEDA, El ingenioso hidalgo don Quijote de la Mancha, parte $6^{\mathrm{a}}$, cap. 15, edic. cit., p. 206). «Don Alejo, en cortesía, nobleza, bizarría y discreción, es digno sujeto de toda alabanza; e Irene en honestidad, gentileza, sangre y condición apacible es honra de sus bellezas y espejo de sus damas» (TIRso DE Molina, Cigarrales de Toledo, edic. de Luis Vázquez Fernández, Madrid, Castalia, 1996, p. 132). Según Antonio Enríquez, en la corte, con unas cuantas «locuras» y "vanidades seguras», "el cuerdo entremetido / será discreto, noble, conocido, / y plaza pasará de caballero, / aunque sea su padre tabernero" (ANTONIO ENRÍQueZ GÓMEZ, El siglo pitagórico y Vida de don Gregorio Guadaña, edic. de Teresa de Santos, Madrid, Cátedra, 1991, p. 326). «Un caballero de la Corte, noble, valiente, discreto, galán, mozo de excelentísimas prendas, pareció necio una tarde con unas damas por reventar de discreto" (BAPTISTA REMIRO DE NAVARRA, Los peligros de Madrid, edic. de María Soledad Arredondo, Madrid, Castalia, 1996, p. 148). «Y, sobre todo, la prenda de las prendas que ha de engastar un caballero es la bondad y la buena intención, no importa la nobleza, la discreción, la gala, la valentía" (ibíd., p. 173). "Entended una cosa, que no hay otro saber como el tener, y el que tiene es sabio, es galán, valiente, noble, discreto y poderoso; es príncipe, es rey y será cuanto él quisiere» (BALTASAR Gracián, El Criticón, parte segunda, crisi $3^{\mathrm{a}}$, edic. cit., vol. II, p. 79). "Éste es - dixo el Sagaz- un hombre que, teniendo una consorte que le dio Dios discreta, noble, rica, hermosa y virtuosa, anda perdido por otra, que le atrazó el diablo, por una moza de cántaro, por una vil y asquerosa ramera, por una fea, por una loca insufrible con quien gasta lo que no tiene» (ibíd., parte II, crisi $9^{\mathrm{a}}$, vol. II, p. 209). « ¡Mal haya Aurora, y sus celos, / que un caballero bizarro, / discreto, dulce y tan digno / de ser querido, a un estado / ha reducido tan triste!» (LOPE DE VEGA, El castigo sin venganza, edic. de David A. Kossof, Madrid, Castalia, 1970, p. 296). "No escuchará sino bien; / que no es todo uno, don Juan, / ser vos el enamorado, / o el bergante de un criado; / que vos sois noble, galán, / rico, discreto, y en fin, / vuestro es amar y querer» (PEDRO CALDERÓN DE LA BARCA, No hay burlas con el amor, jornada I, escena $1^{\text {a }}$, en Comedias, edic. de Juan Eugenio Hartzenbusch, Madrid, Atlas, 1944-1945, 4 vols. (BAE, 7, 9, 12, 14), vol. II, pp. 309-310). Recuérdense, además, títulos de comedias tan significativos como El poder en el discreto, Servir a señor discreto y El castigo del discreto, de Lope de Vega, y Galán, valiente y discreto, de Antonio Mira de Amescua.

${ }^{144}$ Baltasar Gracián, El discreto, en Obras escogidas de filósofos, edic. de Adolfo de Castro, Madrid, Atlas, 1953 (BAE, 65), pp. 540-545. 
También en la obra de Cervantes la discreción es la virtud propia de los personaje que son nobles o están en vías de serlo ${ }^{145}$, aunque en el Quijote, con ademán destructor de mitos e ideas preconcebidas, su posesión se atribuye repetidamente a un labriego como Sancho: "iVálate el diablo por villano, y qué de discreciones dices a las veces! No parece sino que has estudiado» (I, 31, 364), exclama don Quijote; y también: "Cada día, Sancho, te vas haciendo menos simple y más discreto" (II, 12, 720). Con motivo de las bodas de Camacho: «Dígote, Sancho, que si como tienes

${ }^{145}$ En el Quijote, Dorotea es "hermosa, recatada, discreta y honesta» (I, 24, 265). A pesar de su conducta, Cardenio piensa que don Fernando es, o debería ser, un "caballero ilustre, discreto, obligado de mis servicios» (I, 27, 307). A la protagonista de El curioso impertinente, Camila, se la define como una «mujer discreta y honrada" (I, 33, 393). Don Antonio Moreno, el noble que en Barcelona hospeda a don Qujote, es un "caballero rico y discreto, y amigo de holgarse a lo honesto y afable», y su mujer, "una señora principal y alegre, hermosa y discreta" (II, 62, 1132 y 1137). En El amante liberal, Cornelio se nos presenta como «caballero de gentil disposición, hijo de padres muy ricos, y él por su persona muy valiente, muy liberal y muy discreto" (MIGUEL DE CERVANTES, Novelas ejemplares, en Obras completas, edic, cit., vol. II, p. 64). En La Señora Cornelia, a don Antonio de Isunza y don Juan de Gamboa se les define como "caballeros principales, de una edad, muy discretos y grandes amigos", y como "caballeros, galanes, discretos y bien criados» (ibíd., pp. 232). En La fuerza de la sangre, la madre de Rodolfo describe a Leocadia como una muchacha «noble y discreta y medianamente rica» (ibíd., p. 152). Don Juan de Avendaño, uno de los protagonistas de La ilustre fregona, es, según su compañero de aventuras, "caballero lo que es bueno, rico lo que basta, mozo lo que alegra, discreto lo que admira» (ibíd., p. 183). En el Persiles, de Auristela se dice que es "de linaje de reyes y de riquísimo estado», y que "su discreción iguala a su belleza, y sus desdichas a su discreción y a su hermosura» (MIGUel DE CERvanTeS, Los trabajos de Persiles y Sigismunda, lib. I, cap. 2, ibid., p. 872); y el duque de Nemurs, "uno de los que llaman de sangre en este reino, es un caballero bizarro y muy discreto" (ibíd., lib. III, cap. 13, p. 1025). En otros casos, los personajes presentan los términos rústico, zafio y tosco, como antónimos de cortesano y discreto: "Este que viene es El Pastor de Fílida", comenta el Barbero durante el escrutinio de los libros del hidalgo, a lo que el Cura responde: «No es ése pastor, sino muy discreto cortesano» (I, 6, 86). El Canónigo queda admirado de la manera en que el cabrero narra el cuento, "tan lejos de parecer rústico cabrero cuan cerca de mostrarse discreto cortesano" (I, 52, 582). Antes de que tome posesión de su gobierno, don Quijote advierte a Sancho: "Si trujeres a tu mujer contigo (porque no es bien que los que asisten a gobiernos de mucho tiempo estén sin las propias), enséñala, doctrínala y desbástala de su natural rudeza, porque todo lo que suele adquirir un gobernador discreto suele perder y derramar una mujer rústica y tonta» (II, 42, 971). Tras el encantamiento de Dulcinea, don Quijote comenta: «a mí me pareció una labradora tosca y fea, y nonada bien razonada, siendo la discreción del mundo» (II, 32, 899); porque, en efecto, para el hidalgo, "Dulcinea es la hermosa, la discreta, la honesta, la gallarda y la bien nacida, y las demás, las feas, las necias, las livianas y las de peor linaje» (II, 44, 990). Para un estudio más extenso acerca de los significados del término en la obra de Cervantes, véase el trabajo de MARGareT S. BATES, "Discreción" in the Works of Cervantes: A Semantic Study, ya citado. 
buen natural y discreción, pudieras tomar un púlpito en la mano y irte por ese mundo predicando lindezas» (II, 20, 800). En otra ocasión: "Hízolo así don Quijote, pareciéndole que las razones de Sancho más eran de filósofo que de mentecato»(II, 59, 1108). Y la Duquesa, aunque sus palabras escondan a veces otras intenciones, advierte:

De que Sancho el bueno sea gracioso lo estimo yo en mucho, porque es señal que es discreto, que las gracias y los donaires, señor don Quijote, como vuesa merced bien sabe, no asientan sobre ingenios torpes; y pues el buen Sancho es gracioso y donairoso, desde aquí le confirmo por discreto (II, 30, 879).

-Por vida del duque - dijo la duquesa-, que no se ha de apartar de mí Sancho un punto: quiérole yo mucho, porque sé que es muy discreto (II, 31, 885).

Pero donde Cervantes muestra más a las claras su talante revolucionario, es en el episodio de la ínsula Barataria, en el que Sancho, el labriego tonto y simple, y ahora bufón interino en el palacio ducal, despliega ante nuestros ojos una asombrosa inteligencia natural, y resuelve con buen pulso los complicados pleitos y enigmas que se le ofrecen, dando una lección de justicia y buen gobierno a los Duques y a quienes esperaban burlarse de sus dislates, hasta tal punto que el Mayordomo tendrá que reconocer:

...estoy admirado de ver que un hombre tan sin letras como vuesa merced, que a lo que creo no tiene ninguna, diga tales y tantas cosas llenas de sentencias y de avisos, tan fuera de todo aquello que del ingenio de vuesa merced esperaban los que nos enviaron y los que aquí venimos (II, 49, 1025).

\section{Y don Quijote:}

Cuando esperaba oír nuevas de tus descuidos e impertinencias, Sancho amigo, las oí de tus discreciones, de que di por ello gracias particulares al cielo, el cual del estiércol sabe levantar los pobres, y de los tontos hacer discretos (II, 51, 1048).

Tras el episodio del báculo y los escudos, durante el gobierno de la ínsula Barataria:

...los presentes quedaron admirados, y el que escribía las palabras, hechos y movimientos de Sancho no acababa de determinarse si le tendría y pondría por tonto o por discreto (II, 45, 996).

En el mismo episodio, el Mayordomo estaba: 
...tan admirado de sus hechos como de sus dichos, porque andaban mezcladas sus palabras y sus acciones, con asomos discretos y tontos (II, 51, 1045).

Los Duques, en cambio, que han tomado como pasatiempo el burlarse de dos seres bondadosos e indefensos, usándolos de bufones, quedan malparados y en ridículo - «no estaban los duques dos dedos de parecer tontos, pues tanto ahínco ponían en burlarse de dos tontos» (II, 70, 1193)—; y al final es el labriego zafio quien les brinda un modelo vivo de rectitud e inteligencia para gobernar, así que:

Cada día se veen cosas nuevas en el mundo: las burlas se vuelven veras y los burladores se hallan burlados (II, 49, 1025). 